Review

\title{
Campylobacter at the Human-Food Interface: The African Perspective
}

\author{
Nikki Asuming-Bediako ${ }^{1,2}$, Angela Parry-Hanson Kunadu ${ }^{3}$, Sam Abraham ${ }^{1}$ (1) and \\ Ihab Habib 1,4,*(D) \\ 1 School of Veterinary Medicine, College of Science, Health, Education and Engineering, Murdoch University, \\ Perth 6150, Australia; nikkiabed@yahoo.com (N.A.-B.); s.abraham@murdoch.edu.au (S.A.) \\ 2 CSIR-Animal Research Institute, Achimota P.O. Box AH20, Ghana \\ 3 Department of Nutrition and Food Science, University of Ghana, Legon P.O. Box LG134, Ghana; \\ aparry-hanson@ug.edu.gh \\ 4 Veterinary Medicine Department, College of Food and Agriculture, United Arab of Emirates University, \\ Al Ain P.O. Box 1555, UAE \\ * Correspondence: i.habib@murdoch.edu.au; Tel.: +61-8-9360-2434
}

Received: 15 April 2019; Accepted: 20 June 2019; Published: 25 June 2019

\begin{abstract}
The foodborne pathogen Campylobacter is a major cause of human gastroenteritis, accounting for an estimated annual 96 million cases worldwide. Assessment of the true burden of Campylobacter in the African context is handicapped by the under-reporting of diarrhoeal incidents and ineffective monitoring and surveillance programmes of foodborne illnesses, as well as the minimal attention given to Campylobacter as a causative agent of diarrhoea. The present review of the literature highlights the variability in the reported occurrence of Campylobacter in humans and animal food sources across different countries and regions in Africa. Campylobacter infection is particularly prevalent in the paediatric population and has been isolated from farm animals, particularly poultry, and foods of animal origin. The reported prevalence of Campylobacter in children under the age of five years ranges from $2 \%$ in Sudan to $21 \%$ in South Africa. In poultry, the prevalence ranges from $14.4 \%$ in Ghana to $96 \%$ in Algeria. This review also highlights the alarming trend of increased Campylobacter resistance to clinically important antimicrobials, such as ciprofloxacin and erythromycin, in humans and food animals in Africa. This review adds to our understanding of the global epidemiology of Campylobacter at the human-food animal interface, with an emphasis from the African perspective. Interinstitutional and intersectoral collaborations, as well as the adoption of the One Health approach, would be useful in bridging the gaps in the epidemiological knowledge of Campylobacter in Africa.
\end{abstract}

Keywords: campylobacteriosis; developing countries; one health; zoonoses; antimicrobial resistance

\section{Introduction}

Campylobacter is a gram-negative, non-spore forming, curved or spiral bacilli, which are oxygen sensitive and prefer to grow under micro-aerobic conditions [1-3]. Some Campylobacter species are thermotolerant; for instance, Campylobacter jejuni (C. jejuni) and Campylobacter coli (C. coli), which are of critical importance to food safety, grow optimally at $42{ }^{\circ} \mathrm{C}$ [2]. In humans, C. jejuni and C. coli are the main culprits of campylobacteriosis, a very widely recognised enteric illness that can be transmitted to humans through the consumption of undercooked meat, especially poultry, contaminated water and milk, and contact with farm animals such as poultry and livestock [4-7]. It has been widely accepted that improper handling and consumption of contaminated food (notably poultry meat) accounts for the majority of human cases [8,9]. Campylobacteriosis in humans is characterised by watery and/or bloody diarrhoea, abdominal pain, cramps, fever, malaise, and vomiting [10-12]. This is especially 
dangerous for young children who are more prone to dehydration and loss of nutrients, such as sodium and protein, as a consequence of the diarrhoeal illness [13].

The pathogenesis of Campylobacter infection is hypothesised to several mechanisms, however it is not yet fully understood. It has been shown that the expression of genes involved in motility, colonization, epithelial cell invasion, and toxin production play an important role in the disease development $[14,15]$. Several genes (i.e., flaA and $f l h \mathrm{~A}$ ), are essential for the mobility/passage of Campylobacter through the stomach and gut environment [16]. In addition, several proteins (encoded by the $c a d \mathrm{~F}, \operatorname{doc} \mathrm{A}, \operatorname{racR}, \operatorname{vir} \mathrm{B} 11, c i a \mathrm{~B}$, and iam genes) on the surface of Campylobacters have been shown to promote the adherence and invasion of epithelial cells of the intestine $[15,17,18]$. Campylobacter has also been found to excrete several cytotoxins (encoded by the $c d t \mathrm{~A}, c d t \mathrm{~B}, c d t \mathrm{C}$, and $w l a \mathrm{~N}$ genes) that contribute to the development of human illness $[19,20]$. Moreover, $C$. jejuni is able to produce superoxide, dismutase enzyme (encoded by the $\operatorname{sodB}$ marker), which catalyses the breakdown of superoxide radicals and hence play a major role in defending Campylobacters from oxidative damage [21].

In low and middle-income countries, the true incidence of Campylobacter is difficult to determine since there are limited systematic surveillance efforts to detect outbreaks and provide isolates that could be used for source-attribution and risk assessment [22]. The infection with Campylobacter is regarded as hyper-endemic in many developing countries, due to poor food and environmental sanitation, and close contact with animals at domestic settings in rural and agricultural communities, among many other factors [23]. Campylobacter is one of the most frequently isolated bacterial pathogens from the stools of infants with diarrhoea in several developing countries [3,24]. According to the World Health Organisation [9], $40 \%$ of the global foodborne disease burden is inflected on children under the age of five years, with the highest burden per population observed in Africa.

Although antimicrobial therapy is not generally indicated in most campylobacteriosis cases, treatment can decrease the duration and reduces the symptoms if it is initiated early in severe cases that warrant antimicrobial intervention [25]. Macrolides (specifically erythromycin) and fluoroquinolones (specifically ciprofloxacin) are considered as the first- and second-choice of antimicrobials, respectively, for the treatment of severe human Campylobacter infections [9]. It has been claimed that the spread of antibiotic resistant bacteria/genes to humans through the food chain could be promoted by the uncontrolled extensive use of antibiotics for prophylaxis and treatment in the primary animal production [26]. The situation of antimicrobial resistance in Campylobacter is not fully understood across the African continent, despite some reports indicating varying trends at the human-food animal interface $[5,25,27-29]$.

This review collates the knowledge on the epidemiology of Campylobacter in humans and food animals in Africa, antimicrobial resistance patterns, and suggestions for management. Specifically, this review aims at elucidating-(i) the prevalence of Campylobacter in humans, particularly children, across different regions of the African continent; (ii) the prevalence of Campylobacter in foods of animal origin; and (iii) Campylobacter's resistance to antimicrobial agents, notably macrolides and fluoroquinolones.

\section{Prevalence of Campylobacter in Humans}

To facilitate data consolidation and regional comparisons, in this review we collate evidence from literatures based on categorisation of the African continent into five geographical sub-regions (East Africa, Central Africa, West Africa, Southern Africa, and North Africa), in accordance with the United Nations Geoscheme for Africa [30]. Table 1 provides a summary of the published research depicting Campylobacter prevalence rates in humans. 
Table 1. Prevalence Rates of Campylobacter in Humans in Some African Countries.

\begin{tabular}{|c|c|c|c|c|c|c|}
\hline Region/Country & Population & Sample Size & Prevalence $[\%]$ & Genus/Species & Detection Procedure & Reference \\
\hline \multicolumn{7}{|l|}{ EAST AFRICA } \\
\hline \multicolumn{7}{|l|}{ Ethiopia } \\
\hline \multirow{4}{*}{ Jimma/South Western } & \multirow{4}{*}{ Diarrhoeal children under 5 years } & \multirow{4}{*}{227} & 16.7 & Campylobacter & \multirow{4}{*}{ Cultural } & \multirow{4}{*}[5]{} \\
\hline & & & 71.1 & C. jejuni & & \\
\hline & & & 21.1 & C. coli & & \\
\hline & & & 7.9 & C. lari & & \\
\hline Gondar/North Western & Diarrhoeal children under age 5 & 285 & 15.4 & Campylobacter & Cultural & [31] \\
\hline Kola Diba/North Western & Children under age 15 & 153 & 10.5 & Campylobacter & Cultural & [32] \\
\hline \multirow{2}{*}{ Kenya/South Western } & Diarrhoeal children & 156 & 5.8 & Campylobacter & \multirow{2}{*}{ Cultural } & \multirow{2}{*}{ [33] } \\
\hline & Controls & 156 & $1 \%$ & & & \\
\hline Madagascar & Diarrhoeal children 0-60 months old & 2196 & 9.7 & Campylobacter & Cultural & {$[34]$} \\
\hline \multirow{2}{*}{ Malawi/Balantyre/Southern } & Diarrhoeal children & 1941 & 21 & Campylobacter & \multirow{2}{*}{ PCR } & \multirow{2}{*}{ [35] } \\
\hline & Non-diarrhoeal Children & 507 & 14.1 & Campylobacter & & \\
\hline Mozambique & Diarrhoeal children & 529 & 1.7 & Campylobacter & Cultural & [36] \\
\hline \multicolumn{7}{|l|}{ Tanzania } \\
\hline \multirow{3}{*}{ Morogoro/Eastern } & \multirow{3}{*}{ Patients } & \multirow{3}{*}{1195} & 11.5 & Campylobacter & \multirow{3}{*}{$\begin{array}{c}\text { Cultural, } \\
\text { MALDI-TOF }\end{array}$} & \multirow{3}{*}{ [37] } \\
\hline & & & 84.1 & C. jejuni & & \\
\hline & & & 15.9 & C. coli & & \\
\hline Mwanza/Northern & Diarrhoeal children & 300 & 9.7 & Campylobacter & Cultural & {$[38]$} \\
\hline \multirow{3}{*}{ Morogoro/Eastern } & \multirow{3}{*}{ Diarrhoeal patients } & \multirow{3}{*}{632} & 9.3 & Campylobacter & \multirow{3}{*}{$\begin{array}{l}\text { Cultural with } \\
\text { Skirrow's protocol } \\
\text { and PCR }\end{array}$} & \multirow{3}{*}{ [39] } \\
\hline & & & 96.6 & C. jejuni & & \\
\hline & & & 3.4 & C. coli & & \\
\hline
\end{tabular}


Table 1. Cont.

\begin{tabular}{|c|c|c|c|c|c|c|}
\hline Region/Country & Population & Sample Size & Prevalence $[\%]$ & Genus/Species & Detection Procedure & Reference \\
\hline \multirow{5}{*}{ Uganda, Kampala } & \multirow{5}{*}{ Diarrhoeal children } & \multirow{5}{*}{226} & 9.3 & Campylobacter & \multirow{5}{*}{ Cultural } & \multirow{5}{*}{ [27] } \\
\hline & & & 80.9 & C. jejuni & & \\
\hline & & & 9.5 & C. lari & & \\
\hline & & & 4.5 & C. coli & & \\
\hline & & & 4.5 & C. lari/C. jejuni & & \\
\hline \multicolumn{7}{|l|}{ CENTRAL AFRICA } \\
\hline \multirow{3}{*}{$\begin{array}{l}\text { Angola, } \\
\text { Luanda }\end{array}$} & \multirow{2}{*}{ Diarrhoeal children under 5} & 194 & 15 & \multirow{3}{*}{ Campylobacter } & \multirow{3}{*}{ Multiplex PCR } & \multirow{3}{*}{ [40] } \\
\hline & & 98 & 23 & & & \\
\hline & Non diarrhoeal under 5 & 96 & 6 & & & \\
\hline \multicolumn{7}{|l|}{ WEST AFRICA } \\
\hline \multirow{4}{*}{$\begin{array}{l}\text { Burkina Faso, } \\
\text { Ouagadougou }\end{array}$} & \multirow{4}{*}{ Enteritis patients } & \multirow{4}{*}{1246} & 2.3 & Campylobacter & \multirow{4}{*}{ Cultural } & \multirow{4}{*}{ [41] } \\
\hline & & & 51.8 & C. jejuni & & \\
\hline & & & 13.8 & C. coli & & \\
\hline & & & 3.5 & C. upsaliensis & & \\
\hline \multirow{5}{*}{$\begin{array}{l}\text { Ghana } \\
\text { Kumasi }\end{array}$} & \multirow{5}{*}{$\begin{array}{l}\text { Diarrhoeal and urinary tract } \\
\text { infection patients }\end{array}$} & \multirow{5}{*}{202} & 17.3 & Campylobacter & \multirow{5}{*}{ Cultural } & \multirow{5}{*}{ [42] } \\
\hline & & & 40 & C. jejuni & & \\
\hline & & & 2.8 & C. jejuni subs doylei & & \\
\hline & & & 37 & C. coli & & \\
\hline & & & 20 & C.lari & & \\
\hline \multirow{3}{*}{$\begin{array}{c}\text { Liberia } \\
\text { Urban coastal } \\
\text { Rural forest }\end{array}$} & \multirow{3}{*}{ Children 6-59 months } & 859 & & \multirow{3}{*}{ Campylobacter } & \multirow{3}{*}{$\begin{array}{l}\text { Cultural with } \\
\text { Skirrow's protocol }\end{array}$} & \multirow{3}{*}{ [43] } \\
\hline & & 341 urban & 44.9 & & & \\
\hline & & 518 rural & 28 & & & \\
\hline Nigeria & & & & & & \\
\hline
\end{tabular}


Table 1. Cont

\begin{tabular}{|c|c|c|c|c|c|c|}
\hline Region/Country & Population & Sample Size & Prevalence $[\%]$ & Genus/Species & Detection Procedure & Reference \\
\hline Sokoto/North Western & Diarrhoeal patients & 292 & 55 & Campylobacter & Cultural & [44] \\
\hline Sokoto/North Western & Pregnant women & 23 & 70 & Campylobacter & Cultural & [45] \\
\hline \multirow{2}{*}{ Enugu/South Eastern } & \multirow{2}{*}{ Diarrhoeal children } & \multirow{2}{*}{514} & 8.3 & Campylobacter & \multirow{2}{*}{ Cultural } & \multirow{2}{*}{ [46] } \\
\hline & & & 93 & C. jejuni & & \\
\hline \multirow{3}{*}{ Ilorin/Middle Belt } & \multirow{3}{*}{ Diarrhoeal children } & \multirow{3}{*}{306} & 8.2 & Campylobacter & \multirow{3}{*}{$\begin{array}{l}\text { Cultural with Butzler } \\
\text { type media }\end{array}$} & \multirow{3}{*}{ [23] } \\
\hline & & & 56 & C. jejuni & & \\
\hline & & & 44 & C. coli & & \\
\hline \multicolumn{7}{|l|}{ SOUTHERN AFRICA } \\
\hline \multirow{3}{*}{ Venda/Northern } & \multirow{3}{*}{ Human stools } & \multirow{3}{*}{322} & 10.2 & C. jejuni & \multirow{3}{*}{ PCR } & \multirow{3}{*}{ [47] } \\
\hline & & & 6.5 & C. coli & & \\
\hline & & & 3.1 & C.conscisus & & \\
\hline Vhembe/North most & Diarrhoeal stools & 565 & 20.3 & Campylobacter & $\begin{array}{l}\text { Cultural with Cape } \\
\text { Town Protocol, PCR }\end{array}$ & [48] \\
\hline \multirow{3}{*}{$\begin{array}{l}\text { Cape town/ } \\
\text { Coastal }\end{array}$} & \multirow{3}{*}{ Diarrhoeal stools } & \multirow{3}{*}{5443} & 40 & C. jejuni & \multirow{3}{*}{$\begin{array}{l}\text { Cultural with Cape } \\
\text { Town Protocol }\end{array}$} & \multirow{3}{*}{ [49] } \\
\hline & & & 24.6 & C. concius & & \\
\hline & & & 23.6 & C. upsaliensis & & \\
\hline Limpopo, North Eastern & HIV individuals & 60 & 20 & Campylobacter & Cultural & [50] \\
\hline Durban/South Eastern & Diarrhoeal children under 5 & 126 & 21 & Campylobacter & Cultural & [51] \\
\hline \multicolumn{7}{|l|}{ NORTH AFRICA } \\
\hline \multicolumn{7}{|l|}{ Egypt } \\
\hline Assiut/South of Cairo & Human & 80 & 27.5 & Campylobacter & $\begin{array}{l}\text { Cultural and } \\
\text { Molecular }\end{array}$ & [52] \\
\hline $\begin{array}{l}\text { Abu Homos/ } \\
\text { Northern }\end{array}$ & Children & 6562 & 9.37 & Campylobacter & Cultural & [53] \\
\hline
\end{tabular}


Table 1. Cont

\begin{tabular}{|c|c|c|c|c|c|c|}
\hline Region/Country & Population & Sample Size & Prevalence $[\%]$ & Genus/Species & Detection Procedure & Reference \\
\hline \multirow{2}{*}{ North of Cairo } & \multirow{2}{*}{ Rural children } & \multirow{2}{*}{106} & 12.3 & C. jejuni & \multirow{2}{*}{ Cultural } & \multirow{2}{*}[54]{} \\
\hline & & & 2.8 & C. coli & & \\
\hline $\begin{array}{l}\text { South, South East and } \\
\text { North of Cairo }\end{array}$ & Occupational workers & 274 & $8.4 \%$ & Campylobacter & $\begin{array}{l}\text { Biochemical and } \\
\text { Molecular }\end{array}$ & [55] \\
\hline \multirow{3}{*}{ Zagazig/East Nile Delta } & \multirow{3}{*}{ Human } & \multirow{3}{*}{110} & 2.7 & Campylobacter & \multirow{3}{*}{ Molecular } & \multirow{3}{*}{ [56] } \\
\hline & & & 5.2 & C. jejuni & & \\
\hline & & & 3.2 & C. coli & & \\
\hline Giza/Central & Human stools & 48 & 16.66 & Campylobacter & Cultural & [57] \\
\hline Abu Homos/Northern & $\begin{array}{l}\text { Diarrhoeal children under three } \\
\text { years }\end{array}$ & 396 & 10.5 & Campylobacter & Cultural & [58] \\
\hline Cairo & Human & 869 & 16.8 & Campylobacter & Cultural & [59] \\
\hline Sudan (Khartoum) & Diarrhoeal children & 437 & 2 & Campylobacter & Cultural, PCR & {$[60]$} \\
\hline
\end{tabular}




\subsection{East Africa}

In East Africa, Campylobacter infections have been recorded in both rural and urban areas, particularly among children. The prevalence varies between countries (see Table 1), with the highest reported rate being 21\% in diarrhoeal children in Malawi [61]. A cross-sectional study conducted from July to October 2012 in the south-western town of Jimma, Ethiopia, detected the presence of Campylobacter in the stools of $16.7 \%$ of 227 diarrhoeal children under the age of five years [5]. Another study conducted between October 2011 and March 2012 found a prevalence of 15.4\% in 285 diarrhoeal children undergoing treatment at the University of Gondar Hospital in northwest Ethiopia [31]. Both studies found that the frequency of Campylobacter was higher in malnourished children and in those from households that lacked a source of clean water and had direct contact with domestic animals, particularly hens. Interestingly, the education level of the caregiver, family size, or handwashing before preparing food or eating or after defecation showed no statistically significant association with a positive culture of Campylobacter.

In a case-control study conducted in Kisii in south-western Kenya, analysis of 312 stool samples (156 cases and 156 controls) identified the presence of Campylobacter in 5.8\% and 1\% of cases and controls, respectively [33]. In Madagascar, 9.7\% of 2196 diarrhoeal stool samples collected from 14 districts during the 2008-2009 rainy season contained Campylobacter spp. [34]. In the southern Malawian city of Blantyre, 1941 faecal samples were collected between 1997 and 2007 from children hospitalised with diarrhoea-analysis of these samples indicated that $21 \%$ of the samples contained Campylobacter compared with $14 \%$ of the samples from 507 non-diarrhoeic children [35]. An analysis of 529 stool samples collected from diarrhoeal children at the Manhiça District Hospital in southern Mozambique showed a low Campylobacter presence of 1.7\% [36].

In Morogoro in eastern Tanzania, Komba, Mdegela, Msoffe, Nielsen and Ingmer [37] detected Campylobacter in $11.4 \%$ of the stool samples taken from 1195 individuals. The prevalence among symptomatic and young individuals was higher than in asymptomatic and adult individuals. In the northern Tanzanian city of Mwanza, a cross-sectional study of 300 children with acute watery diarrhoea in two hospitals revealed that $9.7 \%$ of the stool samples tested positive for Campylobacter [38]. In another cross-sectional study in rural and urban areas of Morogoro in eastern Tanzania from January 2003 to December 2004, the prevalence of Campylobacter was reported as $9.3 \%$ in 632 human stool samples, with C. jejuni accounting for more than $90 \%$ of the positive isolates [39].

Similar to the studies from Tanzania, Mshana, Joloba, Kakooza and Kaddu-Mulindwa [27] recorded a 9.3\% isolation rate of Campylobacter in 226 stool samples from diarrhoeal children attending the Mulago Hospital in Kampala, the capital city of Uganda, with C. jejuni being the most frequently detected species (80.9\%). Mshana et al. further reported a higher infection rate of $10.9 \%$ in children under two years of age compared with a rate of $8.5 \%$ in children over two years of age. The researchers proposed that the increase in protective antibodies with age may account for the decreased rate of infection in older children.

\subsection{Central Africa}

There are limited published studies from the central African region. An analysis of 194 stool samples from 98 children with acute diarrhoea and 96 children without diarrhoea under the age of five in Angola's capital city of Luanda found that Campylobacter was present in 15\% of the samples overall, with $23 \%$ present in the stools of diarrhoeic children compared with $6 \%$ in the stools of non-diarrhoeic children [40]. Multiplex real-time polymerase chain reaction (mPCR) was used to analyse the samples. Other pathogens, including Escherichia coli, Salmonella, Cryptosporidium, and Shigella, were detected in all the samples, regardless of diarrhoeal status. 


\subsection{West Africa}

In Ouagadougou, the capital of Burkina Faso, Sangaré, Nikiéma, Zimmermann, Sanou, Congo-Ouédraogo, Diabaté, Diandé and Guissou [41] collected stool samples from 1246 enteritis patients from 2006 to 2008 and reported a Campylobacter isolation rate of 2.3\%, with C. jejuni accounting for $51.8 \%$, C. coli accounting for $13.8 \%$, and C. upsaliensis accounting for 3.5\%. In Kumasi, the capital of Ghana, Karikari, Obiri-Danso, Frimpong and Krogfelt [42] reported a Campylobacter prevalence of 17.3\% in 202 patients who visited the Komfo Anokye Teaching Hospital from May to August 2013.

In Liberia, researchers reported a noteworthy Campylobacter isolation rate of $44.9 \%$ in 341 children from a crowded urban slum compared with only $28 \%$ in 518 children from a cleaner rural area. [43]. The children were aged between six months and five years. The authors found that the prevalence of Campylobacter increased in children aged over 18 months, arguing that this may be attributed to increased contact with animals and the environment. Other risk factors for infection were the post-weaning consumption of contaminated food and water.

In Nigeria, Africa's most populous country, analysis of 292 stool samples taken from people in hospitals across four agricultural zones in the north-western state of Sokoto detected the presence of Campylobacter in $55 \%$ of the samples [44]. Another study in the same state found that $70 \%$ of 23 pregnant women and $43 \%$ of 57 non-pregnant women were stool-positive for Campylobacter [45]. In this study, exposure was attributed to poor environmental conditions in the homes of patients [45]. In Enugu, in the south-eastern state of Nigeria, a lower isolation rate of $8.3 \%$ was found in 514 children under the age of five years, with C. jejuni accounting for $93 \%$ of the positive isolates [46]. Similarly, Samuel, Aboderin, Akanbi II, Adegboro, Smith and Coker [23] detected Campylobacter in 8.2\% of the stool samples from 306 diarrhoeal children in Ilorin in the middle belt zone of Nigeria, with all positive isolates being found in children under the age of two years. The authors indicated that the key risk factors were exposure to an unclean environment and the consumption of contaminated foods and water after weaning [23].

\subsection{Southern Africa}

In the Venda region, located in the northern part of South Africa, C. jejuni was detected in $10.2 \%$ of 322 stool samples collected from patients admitted to a hospital [47]. Although other pathogens such as H. pylori, Arcobacter butzleri, A. skirowii, and A. cryaerophilus were also present, C. jejuni was significantly associated with diarrhoea. In another study in South Africa, samples of diarrhoeal stools were taken from 565 people in rural areas in the northernmost district of Vhembe, and analysis using the filtration method detected Campylobacter in $20.3 \%$ of the samples. A higher isolation rate of $30.4 \%$ was seen in the samples taken from children under the age of two [48]. Lastovica [49] analysed 5443 diarrhoeal stool samples collected from the Red Cross Children's Hospital in the coastal city of Cape Town between 1990 and 2005 and found that $40 \%$ contained C. jejuni, 24.6\% contained C. concisus, and $23.6 \%$ contained C. upsaliensis. The isolation was carried out using the Cape Town Protocol, which may have contributed to the high levels detected. In the rural Limpopo province of north-eastern South Africa, Campylobacter was isolated from $20 \%$ of the stool samples taken from $60 \mathrm{HIV}$-positive individuals with chronic diarrhoea [50]. Forty of the 60 individuals tested were positive for other diarrhoeal agents, including E. coli, Shigella, Salmonella, Plesiomonas shigelloides, and Aeromonas spp. HIV infection is known to seriously compromise immunity; hence, patients were susceptible to a wide range of infections. Further, in two interrelated studies undertaken in a Durban hospital, Campylobacter was found in $21 \%$ of the stool samples taken from 126 malnourished inpatient children compared with $7 \%$ of the stool samples taken from 352 randomly selected outpatient children [51]. Other pathogens such as Salmonella, E. coli, and Shigella were isolated from both groups. Malnutrition compromises the body's defence system, thus increasing susceptibility to infection. 


\subsection{North Africa}

A study by Abushahba [52] in Assiut in Egypt, located about $375 \mathrm{~km}$ south of the capital Cairo, found that $27.5 \%$ of 80 human stool samples screened positive for Campylobacter. Of the participants in that study, 33 were infants under the age of 12 months. The key risk factors for infection were impaired immunity and residential conditions in villages, with poor hygiene and poultry rearing in households. In a prospective study conducted in Abu Homos, an agricultural community in northern Egypt, from 1995 to 2003, Campylobacter was isolated from $9.37 \%$ of 6562 faecal samples collected from 1057 children [53]. In the Gharbia Governorate located in the Nile Delta region of Egypt, El-Tras, Holt, Tayel and El-Kady [54] found a prevalence of $12.3 \%$ and $2.8 \%$ for C. jejuni and C. coli, respectively, in 106 rural children from households that owned poultry. Poultry is a major reservoir for Campylobacter and is, therefore, an important source of transmission-backyards or coops with wet litter and poor sanitation increase the risk of human exposure. In Zagazig in the eastern part of the Nile Delta, Awadallah, Ahmed, El-Gedawy and Saad [56] detected a Campylobacter prevalence of $2.7 \%$ in 110 stool samples sourced from the El-Ahrar General Hospital from September 2012 to April 2014. Hassanain [57] reported a higher Campylobacter prevalence of $16.66 \%$ in 48 human faecal samples collected from individuals in contact with food-producing animals in the Giza Governorate in central Egypt.

From 1995 to 1998, a case-control study of 397 children under the age of three years in the Abu Homos region of northern Egypt reported 3477 episodes of diarrhoea of which 366 (10.5\%) were associated with Campylobacter [58]. The presence of animals in the house, particularly in cooking areas, and other unhygienic conditions were major risk factors for infection. Breastfeeding did not appear to reduce the risk of Campylobacter-associated diarrhoea, but a reduced risk was associated with adequate toilet facilities. At Abbassia Fever Hospital in Cairo, 869 Salmonella, Shigella, and Campylobacter strains were isolated from 6278 patients who visited the hospital from January 1986 to December 1993. Although Salmonella was the predominant strain at 53.5\%, Campylobacter showed a prevalence of $16.8 \%$, with C. jejuni present in 92 of the 146 Campylobacter-positive isolates [59].

In Sudan, an isolation rate of $2 \%$ was found in 437 stool samples of diarrhoeal children collected from January to December 2013 in suburban Khartoum [60]. The samples were also colonised by other pathogens, including E. coli, rotavirus A, Shigella, Salmonella, and Giardia intestinalis. Bacterial agents were the most common cause of diarrhoea and children over two years of age were frequently affected. Contaminated hands are a common source of foodborne infections and, given that proper handwashing is a challenge for this age group, this may have been a reason for the increased prevalence of diarrhoea [60].

\section{Prevalence of Campylobacter in Foods of Animal Origin}

Meat, eggs, milk, and other products from animals represent an important part of the diet of Africans [62]. On the African continent, varying rates of Campylobacter prevalence in food of animal origin have been reported ranging from $2 \%$ in beef to $90 \%$ in chicken carcasses. Table 2 provides a summary of the Campylobacter prevalence in foods of animal origin. 
Table 2. Occurrence of Campylobacter in Foods of Animal Origin.

\begin{tabular}{|c|c|c|c|c|c|c|}
\hline Region/Country & Product & Sample Size & Percentage Positive & Genus/Species & Detection Procedure & Reference \\
\hline \multicolumn{7}{|l|}{ EAST AFRICA } \\
\hline \multirow{3}{*}{$\begin{array}{l}\text { Ethiopia/South East Addis } \\
\text { Ababa }\end{array}$} & \multirow{3}{*}{ Sheep and goat carcass } & \multirow{3}{*}{398} & 10.1 & Campylobacter & \multirow{3}{*}{ Cultural } & \multirow{3}{*}{ [63] } \\
\hline & & & 72.5 & C. jejuni & & \\
\hline & & & 27.5 & C.coli & & \\
\hline \multirow{2}{*}{ Kenya/Nairobi } & Chicken & 100 & 77 & \multirow{2}{*}{ Campylobacter } & \multirow{2}{*}{ Cultural } & \multirow{2}{*}[64]{} \\
\hline & Beef & 50 & 2 & & & \\
\hline \multicolumn{7}{|l|}{ Tanzania } \\
\hline \multirow{2}{*}{$\begin{array}{l}\text { Northern, South Western, } \\
\text { Eastern }\end{array}$} & Beef carcass & 253 & 9.5 & \multirow{2}{*}{ Campylobacter } & \multirow{2}{*}{ mPCR } & \multirow{2}{*}{ [65] } \\
\hline & Raw milk & 284 & 13.4 & & & \\
\hline Morogoro/Eastern & Duck intestines & 90 & 80 & Campylobacter & $\begin{array}{c}\text { Cultural with } \\
\text { Skirrow's protocol }\end{array}$ & {$[66]$} \\
\hline Morogo/Eastern & Cattle carcass & 107 & 9.3 & Campylobacter & $\begin{array}{l}\text { Cultural with Skirrow } \\
\text { protocol }\end{array}$ & [67] \\
\hline \multicolumn{7}{|l|}{ CENTRAL AFRICA } \\
\hline Cameroon/Yaounde & Chicken & 150 & 90 & Campylobacter & Cultural & {$[68]$} \\
\hline \multirow{3}{*}{ Congo DR/Lubumbashi } & Goat meat & 177 & 41.2 & \multirow{3}{*}{ Campylobacter } & \multirow{3}{*}{ PCR } & \multirow{3}{*}{ [69] } \\
\hline & Goat stomach & 86 & 37.2 & & & \\
\hline & Ready to eat goat skewer & 139 & 23.7 & & & \\
\hline \multicolumn{7}{|l|}{ WEST AFRICA } \\
\hline Burkina Faso/Ouagadougou & Chicken carcass & 20 & 50 & Campylobacter & Cultural & {$[70]$} \\
\hline Ghana & & & & & & \\
\hline
\end{tabular}


Table 2. Cont.

\begin{tabular}{|c|c|c|c|c|c|c|}
\hline Region/Country & Product & Sample Size & Percentage Positive & Genus/Species & Detection Procedure & Reference \\
\hline \multirow{5}{*}{ Kumasi } & \multirow{5}{*}{ Poultry carcass } & \multirow{5}{*}{132} & 21.9 & Campylobacter & \multirow{5}{*}{ Cultural } & \multirow{5}{*}{ [71] } \\
\hline & & & 79 & C. jejuni & & \\
\hline & & & 14 & C. coli & & \\
\hline & & & 4 & C. jejuni subs doylei & & \\
\hline & & & 3 & C. lari & & \\
\hline \multirow{4}{*}{ Kumasi } & Cattle carcass & 110 & 34.5 & \multirow{4}{*}{ Campylobacter } & \multirow{4}{*}{ Cultural, mPCR } & \multirow{4}{*}[72]{} \\
\hline & Goat carcass & 134 & 23.9 & & & \\
\hline & Sheep carcass & 117 & 35.9 & & & \\
\hline & Pig carcass & 102 & 36.3 & & & \\
\hline \multicolumn{7}{|l|}{ Nigeria } \\
\hline \multirow{2}{*}{ Sokoto/North Western } & \multirow{2}{*}{ Raw milk } & \multirow{2}{*}{146} & 4.8 & Campylobacter & \multirow{2}{*}{ Cultural } & \multirow{2}{*}[73]{} \\
\hline & & & 100 & C. jejuni & & \\
\hline \multirow{3}{*}{ Sokoto/North western } & \multirow{3}{*}{ Chicken } & \multirow{3}{*}{681} & 81.9 & Campylobacter & \multirow{3}{*}{ Cultural } & \multirow{3}{*}{ [74] } \\
\hline & & & 60.9 & C. jejuni & & \\
\hline & & & 39.1 & C.coli & & \\
\hline Senegal/Dakar & Chicken & 300 & 56 & Campylobacter & Cultural & {$[75]$} \\
\hline \multicolumn{7}{|l|}{ SOUTHERN AFRICA } \\
\hline $\begin{array}{l}\text { South Africa } \\
\text { Gauteng/North }\end{array}$ & Chicken carcass & 99 & 32.3 & Campylobacter & Cultural & {$[76]$} \\
\hline \multicolumn{7}{|l|}{ NORTH AFRICA } \\
\hline \multicolumn{7}{|l|}{ Algeria } \\
\hline Middle area & Turkey neck skin & 100 & 55 & Campylobacter & Cultural & [77] \\
\hline
\end{tabular}


Table 2. Cont.

\begin{tabular}{|c|c|c|c|c|c|c|}
\hline Region/Country & Product & Sample Size & Percentage Positive & Genus/Species & Detection Procedure & Reference \\
\hline $\begin{array}{c}\text { Middle area; Algiers, Bouira, } \\
\text { Boumerdes }\end{array}$ & Chicken neck, giblets & 346 & 17.9 & Campylobacter & $\begin{array}{l}\text { Cultural with Butzler } \\
\text { medium and } \\
\text { Skirrow's protocol }\end{array}$ & [78] \\
\hline \multicolumn{7}{|l|}{ Egypt } \\
\hline Assiut/South of Cairo & Chicken & 104 & 24 & Campylobacter & Cultural & [52] \\
\hline Qena city/Southern & Milk, cheese, yogurt & 150 & 24.6 & Campylobacter & Cultural, PCR & [79] \\
\hline \multirow{5}{*}{$\begin{array}{c}\text { Cairo, Minya, Qalubiya and } \\
\text { Fayoum }\end{array}$} & Yogurt & 344 & 1.2 & \multirow{5}{*}{ Campylobacter } & \multirow{5}{*}{ Cultural } & \multirow{5}{*}{ [55] } \\
\hline & Raw milk & 457 & 2.0 & & & \\
\hline & Cheese & 288 & 1.7 & & & \\
\hline & Chicken intestine & 211 & 12.8 & & & \\
\hline & Chicken meat & 9.6 & 680 & & & \\
\hline \multirow{3}{*}{ Zagazig/Eastern Nile Delta } & Chicken breast & 64 & 47.5 & \multirow{3}{*}{ Campylobacter } & \multirow{3}{*}{ Cultural } & \multirow{3}{*}[56]{} \\
\hline & Chicken thighs & 64 & 25.9 & & & \\
\hline & Chicken skin & 64 & 21.6 & & & \\
\hline Abou Homos/Northern & Milk, milk products & 227 & 2.64 & C. jejuni & mPCR & [80] \\
\hline \multirow{3}{*}{$\begin{array}{c}\text { Morocco/ } \\
\text { Oujda/Eastern }\end{array}$} & \multirow{3}{*}{ Poultry carcass } & \multirow{3}{*}{50} & 62 & Campylobacter & \multirow{3}{*}{$\begin{array}{l}\text { Cultural, Hippurate } \\
\text { hydrolysis }\end{array}$} & \multirow{3}{*}{ [81] } \\
\hline & & & 90 & C. jejuni & & \\
\hline & & & 10 & C. coli & & \\
\hline
\end{tabular}




\subsection{East Africa}

Sheep and goat meat are an important part of the Ethiopian diet. A cross-sectional study of 398 sheep and goat carcasses from a private export abattoir in Debre-Zeit, $45 \mathrm{~km}$ south-east of Addis Ababa, between October 2007 and March 2008 found that Campylobacter was present in 10.1\% of the samples, with $C$. jejuni accounting for $72 \%$ of the isolates [63]. The highest bacterial isolation was from the breast region of the carcasses, resulting from cross-contamination from intestinal contents during manual skinning, evisceration, processing, and contact with processors' hands or knives. Additionally, washing of carcasses carries microorganisms from other parts of the body to the breast region. Therefore, effective hygienic practices and attentive evisceration during slaughter and dressing are important measures to reduce contamination.

In Kenya, Osano and Arimi [64] analysed 100 chicken and 50 beef samples from butchers, supermarkets, and markets in Nairobi and reported the presence of Campylobacter in 77\% and 2\% of chicken and beef samples, respectively. C. jejuni was the dominant species isolated from chicken, emphasising its potential role in zoonotic transmission between humans and poultry. In Tanzania, Kashoma, Kassem, John, Kessy, Gebreyes, Kazwala and Rajashekara [65] reported the presence of Campylobacter in $9.5 \%$ of 253 beef carcasses and $13.4 \%$ of 284 unpasteurised raw milk samples using mPCR. This was conducted from April 2013 to March 2014 and samples were sourced from Arusha, Iringa and Morogoro in Tanzania. The milk was obtained from milk vendors and milk tanks at milk collecting centres, while the beef swabs were taken from dressed carcasses. This study illustrates that the consumption of raw milk is a route for the transmission of Campylobacter. Cattle also carry C. jejuni and cross-contamination could occur during slaughter and milking. Therefore, slaughter and milking should be carried out using hygienic methods to minimise the transmission of pathogens to meat and milk and, consequently, to humans. Similarly, Campylobacter was detected in $9.3 \%$ of 107 cattle carcasses sampled from an abattoir in Morogoro in east Tanzania, while in meat shops, it was detected in $1.7 \%$ of samples [67]. The authors reported that the dressing and sale of meat was carried out in unhygienic environments and some shops sold chicken in addition to beef, thereby enhancing the risk of transfer.

\subsection{Central Africa}

In Cameroon, Nzouankeu, Ngandjio, Ejenguele, Njine and Wouafo [68] reported that 90\% of 150 retail chickens obtained from eight markets in the capital Yaounde from February 2006 to January 2007 contained Campylobacter spp.. E. coli and Salmonella were also isolated from the samples using culture-based methods. Campylobacter is commensal in poultry, its primary host, and the risk of cross-contamination to the carcass during slaughter and processing is high if this is not carried out carefully and hygienically. Nzouankeu et al. further suggested the need to monitor poultry for pathogens and to minimise cross-contamination.

In a study of retail goat meat outlets in Lubumbashi in the Democratic Republic of the Congo, Campylobacter was found in $41.2 \%$ of 177 goat meat samples, $37.2 \%$ of 86 goat stomach samples, and $23.7 \%$ of 139 ready-to-eat goat skewers using polymerase chain reaction (PCR) [69]. The outlets comprised open air and semi-open-air markets, snack bars, and bars. The authors noted that the slaughter of animals was undertaken in unhygienic facilities and retail points, and no efforts were made to ward off flies or other vermin. However, cooking decreased the prevalence of Campylobacter, as evidenced by the lower rate recorded in the ready-to-eat goat skewers sourced from the same outlets. Thorough cooking of meat is an effective way of reducing the risk of infection in humans.

\subsection{West Africa}

In Ouagadougou, Burkina Faso, Campylobacter was detected in $50 \%$ of 20 poultry carcasses sourced from retail markets [70]. The carcasses were sold on tables in ambient temperatures without protection from dust or flies, the vendors did not wear gloves or aprons, and the retail environment was infested with lizards, rodents, and avian species. Kagambèga, Thibodeau, Trinetta, Soro, Sama, Bako, Bouda, 
Wereme N'Diaye, Fravalo and Barro [70] suggested that, although poultry is widely consumed in Burkina Faso, patients with diarrhoea are not routinely sampled for Campylobacter. However, in neighbouring Ghana, a lower isolation rate of $21.9 \%$ was detected in 132 poultry carcasses randomly selected from the Kejetia poultry slaughter unit in Kumasi [71]. Campylobacter is known to colonise the intestinal tract of poultry and cross-contamination can occur during slaughtering and processing if the carcass is not properly handled. Karikari, Obiri-Danso, Frimpong and Krogfelt [72] found that Campylobacter were present in $34.5 \%$ of beef, $23.9 \%$ of goat, $35.9 \%$ of sheep, and $36.3 \%$ of pig carcasses sampled from the Kumasi abattoir. The contamination of carcasses during manual skinning, evisceration, and processing at the abattoir were the reasons attributed to the prevalence rates recorded.

In Sokoto in north-western Nigeria, Salihu, Junaidu, Magaji and Rabiu [73] detected the presence of Campylobacter in 4.8\% of 146 raw milk samples from lactating herds between October 2007 and September 2008. All the positive samples contained C. jejuni biotype I. The authors suggested that animal and animal products were reservoirs for human infections. Analysis of breed distribution showed that White Fulani breeds had a higher prevalence (5.4\%) than Sokoto Gudali breeds (4.7\%) or Friesian-Sokoto Gudali crossbreeds (0.0\%). Using culture methods, Salihu, Junaidu, Magaji, Abubakar, Adamu and Yakubu [74] detected Campylobacter in $81.9 \%$ of 681 chicken samples in Sokoto from November 2007 to October 2008. C. jejuni accounted for $60.9 \%$ of the isolates, followed by C. coli at $28 \%$, and C. lari at $7 \%$. Biotyping showed a prevalence of biotype I in C. jejuni, C. coli, and C. lari. C. jejuni I and C. coli I are found in humans; hence, the results were indicative of the zoonotic nature of the pathogen.

From January 2001 to May 2002, 300 fresh, refrigerated, or frozen chicken carcasses from retail outlets in Dakar in Senegal were analysed, with Campylobacter being present in $56 \%$ of the samples [75]. The contamination rates were found to be highest in the fresh samples at $76 \%$ and lowest in the frozen samples at $28 \%$. Fifty-three percent of the refrigerated samples were also contaminated. Campylobacter is stress sensitive and freezing affects its viability, hence the lower rates found in frozen samples. Therefore, hygienic handling practices during slaughter and processing, and adequate personal hygiene and cooking techniques are important for infection control.

\subsection{Southern Africa}

In South Africa, van Nierop, Duse, Marais, Aithma, Thothobolo, Kassel, Stewart, Potgieter, Fernandes, Galpin and Bloomfield [76] found that Campylobacter was present in 32.3\% of 99 fresh and frozen chicken carcasses sourced from retailers in Gauteng in the country's north. Carcasses from supermarkets were more frequently contaminated with Campylobacter than those from butchers, which were more frequently contaminated with Salmonella. Similarly, in a study in Senegal, Campylobacter was isolated more frequently from fresh chicken than from frozen chicken. Culture methods detected an isolation rate of $32.3 \%$, whereas PCR detected a rate of $43.4 \%$. Detection methods play a key role in detecting prevalence, with PCR reported to be more sensitive in the detection of pathogens. However, the authors cautioned that the use of PCR may have resulted in false positives because of DNA contamination, the presence of inhibitory substances in the enrichment broths or the identification of non-viable pathogens as viable.

\subsection{North Africa}

In Algeria, Bouhamed, Bouayad, Messad, Zenia, Naim and Hamdi [77] found that Campylobacter was present in 55\% of 100 turkey neck skins sampled from three traditional and one modern abattoir located in the country's middle regions, Algiers, Bouïra, and Boumèrdes. The abattoirs were characterised by a lack of disinfection protocols and sterilisation of equipment, and by the use of dirty uniforms. These are important factors that enhance the spread of pathogens. However, Laidouci, Mouffok and Hellal [78] found a lower presence of Campylobacter (17.9\%) in 346 chicken neck and giblets sourced from Algeria. 
In Egypt, 24\% of 104 chicken carcasses from two slaughterhouses in the Assiut Governorate south of Cairo contained Campylobacter [52]. An analysis of 150 raw milk, kareish cheese, and yoghurt samples from September 2014 to February 2015 found that 24.6\% tested positive for Campylobacter spp. [79]. All the samples tested positive for C. jejuni and negative for C. coli. The samples were obtained from the local market and street vendors in the city of Qena in southern Egypt. After the samples were cultured, MPCR was used to confirm the isolates. The presence of Campylobacter in raw milk was attributed to contamination during on-farm milking processes or to poor post-milking storage and handling conditions. Unhygienic methods used in the preparation, processing, handling, and sales of kareish cheese accounted for it having the highest presence of Campylobacter among the products tested. In a study conducted across the governorates of Cairo, Minya, Qalyubia, and Fayoum in Egypt, Omara, Fadaly and Barakat [55] found that Campylobacter was present in $12.8 \%$ of raw chicken intestines, $9.6 \%$ of 680 raw chickens, $1.2 \%$ of 344 yoghurt samples, $2.0 \%$ of 457 raw milk samples, and $1.7 \%$ of 288 kareish cheese samples. The contamination was attributed to unsanitary food production and storage practices. Further, Awadallah, Ahmed, El-Gedawy and Saad [56] found that Campylobacter was present in $47.5 \%, 25.9 \%$, and $21.6 \%$ of chicken skins, chicken thighs, and chicken breasts, respectively. These products were sourced from a slaughterhouse in Zagazig, a city in the eastern part of the Nile Delta-the authors found that refrigeration and particularly freezing reduced the counts of viable Campylobacter cells. In contrast, in Abu Homos in northern Egypt, a study detected Campylobacter in only $2.64 \%$ of 227 milk and milk product samples [80]. Using culture methods and mPCR assays, raw milk and fresh domiati cheese (a moderately slated enzyme-coagulated soft cheese) samples tested positive for Campylobacter. The remaining milk products, laban rayeb (traditional low-fat fermented milk), stored domiati cheese (a highly salted enzyme-coagulated soft cheese), zabady (Egyptian yoghurt), ras cheese (a hard cheese variety), and kareish cheese (an acid-coagulated soft cheese) were all negative for Campylobacter. The products that tested positive were contaminated with C. jejuni, which had survived preservation methods better than expected, implying that the pathogen has the ability to develop adaptive strategies to aid survival in food preservation conditions.

In Morocco, Campylobacter was detected in $62 \%$ of 50 retail poultry samples sourced from the Oujda area in the eastern part of the country [81]. Similar to other countries, the high level of contamination was attributed to poultry being the primary host of Campylobacter and cross-contamination occurring at unhygienic slaughter and retail points. The authors further identified the antibacterial effects of common condiments, finding that that $1 \% \mathrm{v} / \mathrm{v}$ lemon juice and vinegar and $2 \% \mathrm{v} / \mathrm{v}$ cinnamon and sodium chloride had high inhibitory effects. However, onion, ginger, black pepper, cumin, parsley, garlic, and saffron had minimal or no effect.

\section{Antimicrobial Resistance (AMR) Patterns of Campylobacter in Africa}

According to the World Health Organisation [22], surveillance of AMR in Campylobacter has identified important levels of resistance to erythromycin and fluoroquinolones in many parts of the world, which appears to be associated with the use of these drugs in poultry and livestock production systems. Some epidemiological studies in humans and animals have established a relationship between antibiotic use and antimicrobial resistance [82-84]. Campylobacteriosis is typically a self-limiting disease, which does not usually require antibiotic treatment; however, in some cases, antibiotics may be administered. Fluoroquinolones and macrolides such as ciprofloxacin and erythromycin, respectively, are recommended for the treatment of Campylobacter infections in humans [24,85]. However, given their abuse and misuse, resistance to these drugs has emerged. Resistance to macrolides such as erythromycin and azithromycin is primarily attributed to mutations in the m23SRNA gene and decreased permeability of Campylobacter cell walls, while resistance to fluoroquinolone is typically moderated by mutation of DNA gyrase and efflux through the outer and inner membranes [86].

In this review we will focus on the resistance patterns of Campylobacter spp. from African environments especially to fluoroquinolones and macrolides as these antimicrobials are the most commonly used for the treatment of Campylobacter infections in humans. Table 3 provides a summary of resistance trends. 
Table 3. Antibiotic Resistance Trends of Campylobacter in Some African Countries.

\begin{tabular}{|c|c|c|c|c|c|c|}
\hline Region/Country & Source & Species & Antibiotic & Resistance \% & Method Used & Reference \\
\hline \multicolumn{7}{|l|}{ EAST AFRICA } \\
\hline \multirow{2}{*}{ Ethiopia/South Western } & \multirow{2}{*}{$\begin{array}{l}\text { Humans, diarrhoeal } \\
\text { children }\end{array}$} & \multirow{2}{*}{ Campylobacter } & Tetracycline & 39.5 & \multirow{2}{*}{$\begin{array}{l}\text { Kirby-Bauer Disk } \\
\text { Diffusion }\end{array}$} & \multirow{2}{*}[5]{} \\
\hline & & & Chloramphenicol & 31.6 & & \\
\hline \multirow{4}{*}{$\begin{array}{c}\text { Kenya, } \\
\text { North eastern Nairobi }\end{array}$} & \multirow{4}{*}{ Backyard chicken } & \multirow{4}{*}{ C. jejuni } & Tetracycline & 71 & \multirow{4}{*}{ PCR } & \multirow{4}{*}{ [87] } \\
\hline & & & Ciprofloxacin & 71 & & \\
\hline & & & Nalidixic acid & 77.4 & & \\
\hline & & & Chloramphenicol & 25.8 & & \\
\hline \multirow{4}{*}{ Mozambique } & \multirow{4}{*}{ Diarrhoeal children } & \multirow{4}{*}{ Campylobacter } & Tetracycline & 22 & \multirow{4}{*}{ Disk Diffusion } & \multirow{4}{*}{ [36] } \\
\hline & & & Ciprofloxacin & 11 & & \\
\hline & & & Chloramphenicol & 11 & & \\
\hline & & & Nalidixic acid & 11 & & \\
\hline \multicolumn{7}{|l|}{ Tanzania } \\
\hline Morogo/Eastern & Free range ducks & Campylobacter & Erythromycin & $20-50$ & Disk Diffusion & {$[66]$} \\
\hline \multirow{9}{*}{$\begin{array}{c}\text { Iringa/North, } \\
\text { Morogoro/Eastern } \\
\text { Arusha/South West }\end{array}$} & \multirow{9}{*}{ Milk, beef } & \multirow{9}{*}{ Campylobacter } & Ciprofloxacin & 9.3 & Disk Diffusion & \multirow{9}{*}{ [65] } \\
\hline & & & Erythromycin & 53.7 & & \\
\hline & & & Tetracycline & 18.5 & & \\
\hline & & & Azithromycin & 42.6 & & \\
\hline & & & Nalidixic acid & 64.8 & & \\
\hline & & & Chloramphenicol & 13 & & \\
\hline & & & Ciprofloxacin & 11.8 & & \\
\hline & & & Erythromycin & 70.6 & Broth micro-dilution & \\
\hline & & & Tetracycline & 17.7 & & \\
\hline
\end{tabular}


Table 3. Cont.

\begin{tabular}{|c|c|c|c|c|c|c|}
\hline Region/Country & Source & Species & Antibiotic & Resistance \% & Method Used & Reference \\
\hline Morogoro/Eastern & Humans & Campylobacter & Ciprofloxacin & 22.1 & Disk Diffusion & [37] \\
\hline Uganda/Kampala & Humans & Campylobacter & Ciprofloxacin & 5 & Disk Diffusion & [27] \\
\hline \multicolumn{7}{|l|}{ WEST AFRICA } \\
\hline \multirow{4}{*}{ Burkina Faso/Ouagadougou } & \multirow{4}{*}{ Humans } & \multirow{4}{*}{ Campylobacter } & Ciprofloxacin & 13.8 & \multirow{4}{*}{ Disk Diffusion } & \multirow{4}{*}{ [41] } \\
\hline & & & Tetracycline & 10.3 & & \\
\hline & & & Erythromycin & 10.3 & & \\
\hline & & & Nalidixic acid & 34.5 & & \\
\hline \multirow{6}{*}{ Ivory Coast/Abidjan } & \multirow{6}{*}{ Chicken } & \multirow{3}{*}{ C. jejuni } & Ciprofloxacin & 38.5 & \multirow{3}{*}{ Disk Diffusion } & \multirow{6}{*}{ [6] } \\
\hline & & & Erythromycin & 10.3 & & \\
\hline & & & Nalidixic acid & 79.5 & & \\
\hline & & \multirow{3}{*}{ C. coli } & Ciprofloxacin & 43.2 & \multirow{3}{*}{ Disk Diffusion } & \\
\hline & & & Erythromycin & 8.1 & & \\
\hline & & & Nalidixic acid & 78.4 & & \\
\hline \multicolumn{7}{|l|}{ Ghana } \\
\hline \multirow{2}{*}{ Kumasi/South } & \multirow{2}{*}{ Humans } & \multirow{2}{*}{ Campylobacter } & Erythromycin & 92.3-100 & \multirow{2}{*}{ Disk Diffusion } & \multirow{2}{*}{ [42] } \\
\hline & & & Tetracycline & $92.3-93.3$ & & \\
\hline \multirow{3}{*}{ Kumasi/South } & \multirow{3}{*}{$\begin{array}{l}\text { Poultry carcass and } \\
\text { faeces }\end{array}$} & \multirow{3}{*}{ Campylobacter } & Quinolones & $41-86$ & \multirow{3}{*}{$\begin{array}{l}\text { Kirby-Bauer Disk } \\
\text { Diffusion }\end{array}$} & \multirow{3}{*}[71]{} \\
\hline & & & Erythromycin & 100 & & \\
\hline & & & Tetracycline & 97-100 & & \\
\hline \multirow{3}{*}{ Kumasi/South } & \multirow{3}{*}{ Livestock } & \multirow{3}{*}{ Campylobacter } & Quinolones & $7-69$ & \multirow{3}{*}{$\begin{array}{c}\text { Kirby-Bauer Disk } \\
\text { Diffusion }\end{array}$} & \multirow{3}{*}{ [72] } \\
\hline & & & Erythromycin & $97-100$ & & \\
\hline & & & Tetracycline & $48-94$ & & \\
\hline
\end{tabular}


Table 3. Cont.

\begin{tabular}{|c|c|c|c|c|c|c|}
\hline Region/Country & Source & Species & Antibiotic & Resistance \% & Method Used & Reference \\
\hline \multicolumn{7}{|l|}{ Nigeria } \\
\hline Sokoto/North Western & Poultry cloacal swabs & Campylobacter & Erythromycin & 11.6 & Disk Diffusion & [88] \\
\hline \multirow{4}{*}{ Osogbo/South Western } & \multirow{4}{*}{ Humans } & \multirow{4}{*}{ Campylobacter coli } & Ciprofloxacin & 0 & \multirow{4}{*}{$\begin{array}{l}\text { Kirby-Bauer Disk } \\
\text { Diffusion }\end{array}$} & \multirow{4}{*}{ [25] } \\
\hline & & & Nalidixic acid & 66 & & \\
\hline & & & Erythromycin & 0 & & \\
\hline & & & Tetracycline & 0 & & \\
\hline \multirow{4}{*}{ Ilorin/Middle belt } & \multirow{4}{*}{ Humans } & \multirow{4}{*}{ Campylobacter } & Ciprofloxacin & 0 & \multirow{4}{*}{$\begin{array}{l}\text { Kirby-Bauer Disk } \\
\text { Diffusion }\end{array}$} & \multirow{4}{*}{ [23] } \\
\hline & & & Erythromycin & 0 & & \\
\hline & & & Nalidixic acid & 24 & & \\
\hline & & & Tetracycline & 12 & & \\
\hline \multicolumn{7}{|l|}{ SOUTHERN AFRICA } \\
\hline \multirow{2}{*}{ Durban/South Eastern } & Humans & \multirow{2}{*}{ Campylobacter } & \multirow{2}{*}{ Tetracycline } & 64 & \multirow{2}{*}{ PCR } & \multirow{2}{*}{ [89] } \\
\hline & Chicken & & & 68 & & \\
\hline \multirow{4}{*}{ Durban/South Eastern } & \multirow{4}{*}{ Humans } & \multirow{2}{*}{ C. jejuni } & Erythromycin & 31.5 & \multirow{4}{*}{ Broth microdilution } & \multirow{4}{*}{ [90] } \\
\hline & & & Azithromycin & 50 & & \\
\hline & & \multirow{2}{*}{ C. coli } & Erythromycin & 38.9 & & \\
\hline & & & Azithromycin & 77 & & \\
\hline
\end{tabular}


Table 3. Cont

\begin{tabular}{|c|c|c|c|c|c|c|}
\hline Region/Country & Source & Species & Antibiotic & Resistance \% & Method Used & Reference \\
\hline \multirow{16}{*}{ Vende/Northern } & \multirow{4}{*}{ Cattle } & \multirow{8}{*}{ C. jejuni } & Ciprofloxacin & 33.3 & \multirow{16}{*}{ Disk diffusion } & \multirow{16}{*}{ [91] } \\
\hline & & & Erythromycin & 42.9 & & \\
\hline & & & Nalidixic acid & 26.2 & & \\
\hline & & & Tetracycline & 31 & & \\
\hline & \multirow{4}{*}{ Chicken } & & Ciprofloxacin & 29 & & \\
\hline & & & Erythromycin & 56.7 & & \\
\hline & & & Nalidixic acid & 47.8 & & \\
\hline & & & Tetracycline & 33.3 & & \\
\hline & \multirow{4}{*}{ Cattle } & \multirow{8}{*}{ C. coli } & Ciprofloxacin & 56.3 & & \\
\hline & & & Erythromycin & 6.8 & & \\
\hline & & & Nalidixic acid & 37.5 & & \\
\hline & & & Tetracycline & 62.5 & & \\
\hline & \multirow{4}{*}{ Chicken } & & Ciprofloxacin & 37.5 & & \\
\hline & & & Erythromycin & 43.8 & & \\
\hline & & & Nalidixic acid & 31.3 & & \\
\hline & & & Tetracycline & 43.8 & & \\
\hline
\end{tabular}


Table 3. Cont

\begin{tabular}{|c|c|c|c|c|c|c|}
\hline Region/Country & Source & Species & Antibiotic & Resistance \% & Method Used & Reference \\
\hline \multirow{12}{*}{ Kwazulu Natal } & \multirow{3}{*}{$\begin{array}{l}\text { Commercial free } \\
\text { range broilers }\end{array}$} & \multirow{12}{*}{ Campylobacter } & Tetracycline & 100 & \multirow{12}{*}{ Agar Dilution } & \multirow{12}{*}{ [92] } \\
\hline & & & Ciprofloxacin & 95.4 & & \\
\hline & & & Erythromycin & 87.9 & & \\
\hline & \multirow{3}{*}{ Rural birds } & & Tetracycline & 21.6 & & \\
\hline & & & Ciprofloxacin & 7.9 & & \\
\hline & & & Erythromycin & 0 & & \\
\hline & \multirow{3}{*}{ Industrial broiler } & & Tetracycline & 98.9 & & \\
\hline & & & Ciprofloxacin & 15.9 & & \\
\hline & & & Erythromycin & 47.6 & & \\
\hline & \multirow{3}{*}{ Industrial layer } & & Tetracycline & 100 & & \\
\hline & & & Ciprofloxacin & 17.7 & & \\
\hline & & & Erythromycin & 43.7 & & \\
\hline \multirow{8}{*}{ Kwazulu Natal } & \multirow{5}{*}{ Broiler } & \multirow{8}{*}{ Campylobacter } & Tetracycline & 98.2 & \multirow{8}{*}{ Agar Dilution } & \multirow{8}{*}{ [28] } \\
\hline & & & Erythromycin & 50 & & \\
\hline & & & Ciprofloxacin & 8.9 & & \\
\hline & & & Nalidixic acid & 35.7 & & \\
\hline & & & Tetracycline & 100 & & \\
\hline & \multirow{3}{*}{ Layer } & & Erythromycin & 42.9 & & \\
\hline & & & Ciprofloxacin & 23.8 & & \\
\hline & & & Nalidixic acid & 52.4 & & \\
\hline
\end{tabular}


Table 3. Cont

\begin{tabular}{|c|c|c|c|c|c|c|}
\hline Region/Country & Source & Species & Antibiotic & Resistance \% & Method Used & Reference \\
\hline \multicolumn{7}{|l|}{ NORTH AFRICA } \\
\hline \multicolumn{7}{|l|}{ Algeria } \\
\hline \multirow{4}{*}{ Bouira/Middle area } & \multirow{4}{*}{ Turkey carcasses } & \multirow{4}{*}{ Campylobacter } & Tetracycline & 81.3 & \multirow{4}{*}{ Disk Diffusion } & \multirow{4}{*}{ [77] } \\
\hline & & & Ciprofloxacin & 75 & & \\
\hline & & & Erythromycin & 25 & & \\
\hline & & & Nalidixic acid & 87.5 & & \\
\hline \multirow{4}{*}{$\begin{array}{c}\text { Middle area/Algiers, Bouira \&, } \\
\text { Boumerdes }\end{array}$} & \multirow{4}{*}{$\begin{array}{l}\text { Sheep, calves broiler } \\
\text { carcasses }\end{array}$} & \multirow{4}{*}{ Campylobacter } & Ciprofloxacin & 91.6 & \multirow{4}{*}{ Disk Diffusion } & \multirow{4}{*}{ [29] } \\
\hline & & & Erythromycin & 88.5 & & \\
\hline & & & Tetracycline & 44.7 & & \\
\hline & & & Nalidixic acid & 96.8 & & \\
\hline \multicolumn{7}{|l|}{ Egypt } \\
\hline \multirow{6}{*}{ Giza } & \multirow{4}{*}{ Poultry } & \multirow{6}{*}{ Campylobacter } & Erythromycin & 58.8 & \multirow{6}{*}{ Disk Diffusion } & \multirow{6}{*}{ [57] } \\
\hline & & & Tetracycline & 58.8 & & \\
\hline & & & Chloramphenicol & 64.7 & & \\
\hline & & & Erythromycin & 50 & & \\
\hline & \multirow[t]{2}{*}{ Human } & & Tetracycline & 75 & & \\
\hline & & & Chloramphenicol & 50 & & \\
\hline \multirow{8}{*}{ Cairo } & \multirow{8}{*}{ Human } & & Nalidixic acid & 40 & \multirow{8}{*}{ Disk diffusion } & \multirow{8}{*}{ [59] } \\
\hline & & 0 & Tetracycline & 6 & & \\
\hline & & с. јејипь & Erythromycin & 9 & & \\
\hline & & & Chloramphenicol & 3 & & \\
\hline & & \multirow{4}{*}{ C. coli } & Nalidixic acid & 24 & & \\
\hline & & & Tetracycline & 24 & & \\
\hline & & & Erythromycin & 10 & & \\
\hline & & & Chloramphenicol & 0 & & \\
\hline
\end{tabular}




\subsection{East Africa}

In Jimma, Ethiopia, erythromycin, ciprofloxacin, gentamicin, and nalidixic acid were reportedly effective for more than $80 \%$ of Campylobacter species isolated from diarrhoeal children using the Kirby-Bauer disc diffusion method. However, $39.5 \%$ of the isolates were resistant to tetracycline and $31.6 \%$ to chloramphenicol, while resistance to ciprofloxacin and erythromycin was $12.0 \%$ [5]. Multidrug resistance was also observed in $78.9 \%$ of the isolates. The high resistance to tetracycline, for example, is attributed to its wide availability without prescription; hence, overuse may have resulted in selective pressure on bacteria, thereby making them resistant.

In Kenya, $74 \%$ of $C$. jejuni isolates from backyard chickens in Thika, north east of the capital Nairobi, showed resistance to nalidixic acid, while $71 \%$ were resistant to each of tetracycline and ciprofloxacin [87]. In that study in Kenya [86], the uncontrolled use and ease of access to antibiotics by small-scale farmers were suggested as reasons for the high resistance rates recorded. In Mozambique, a resistance rate of $11 \%$ was reported for ciprofloxacin and nalidixic acid in stool samples of diarrhoeal children at the Manhica Hospital [36]. Such relatively low rates might be expected as the use of fluoroquinolones is not recommended in young children [36].

In Tanzania, Campylobacter isolates from milk and beef collected from the Eastern (Morogoro), Northern (Arusha) and South Western (Iringa) parts of the country showed resistance to ciprofloxacin ranged from $9.3 \%$ to $11.8 \%$, while the range for erythromycin resistance was between $53.7 \%$ and $70.6 \%$ [65]. The authors also noted that, in Tanzania, the macrolide, Tylosin, was extensively used for treating respiratory infections like Mycoplasma in cattle and its usage for treatment and growth promotion might have contributed to the selection of resistant strains to erythromycin. Furthermore, isolates from free-range ducks in the same city, were susceptible to nitrofurantoin and amikacin, while they showed $74 \%$ resistance to tetracycline [66].

\subsection{West Africa}

In Burkina Faso, isolates from human stools showed 13.8\% resistance to ciprofloxacin, $10.3 \%$ to tetracycline, and 10.3\% to erythromycin [41]. A study in Abidjan, Ivory Coast Goualie, Essoh, Elise Solange, Natalie, Souleymane, Lamine Sebastien and Mireille [6], reported 79.5\%, 38.5\%, $17.9 \%$, and $10.3 \%$ resistance of poultry C. jejuni isolates to nalidixic acid, ciprofloxacin, amoxicillin, and erythromycin, respectively. C. coli, on the other hand, showed resistance rates of $78.4 \%, 43.2 \%$, $13.5 \%$, and $8.1 \%$ to nalidixic acid, ciprofloxacin, amoxicillin, and erythromycin, respectively. The authors noted that the unrestricted use of antibiotics for treatment and as growth promoters contributed to the resistance.

In neighbouring Ghana, a resistance of $92.3-100 \%$ was reported for erythromycin, $92.3-93.3 \%$ for tetracycline, and $0 \%$ for imipenem for isolates from patients in Kumasi [42]. Erythromycin resistance arises as a result of prolonged exposure and evidently, as noted by the authors, erythromycin had been on the Ghanaian market for a long time and was subjected to abuse and misuse. Additionally, the isolates from carcasses and faeces of poultry in Kumasi were all completely sensitive to imipenem. However, the resistance to quinolones ranged from $41-86 \%, 100 \%$ to erythromycin and $97-100 \%$ to tetracycline [71]. Furthermore, the isolates from livestock showed $7-69 \%$ resistance to quinolones, $97-100 \%$ to erythromycin, and $48-94 \%$ to tetracycline. There was $0 \%$ resistance to imipenem [72]. In Sokoto, (North Western Nigeria), the isolates from cloacal swabs of poultry showed resistance to most of the antibiotics except chloramphenicol. Multidrug-resistant traits were found in $82.1 \%$ of the isolates. Resistance to ciprofloxacin was $19.6 \%$, ampicillin $32.1 \%$, tetracycline $24.1 \%$, and erythromycin $11.6 \%$ [88]. Due to the low levels of resistance recorded for erythromycin, it was recommended for treatment. The zero resistance to chloramphenicol was because it had been banned for use in both humans and animals [88]. Additionally, in Ilorin in the middle belt of Nigeria, Samuel, Aboderin, Akanbi II, Adegboro, Smith and Coker [23] reported resistance of human isolates to nalidixic acid $(24 \%)$ and tetracycline (12\%) but the isolates showed no resistance to erythromycin and ciprofloxacin. Besides, the isolates from diarrhoeal stools of children below age 3 years in Osogbo, South Western 
Nigeria [25], were reported to be sensitive to erythromycin, tetracycline, and ciprofloxacin, and were hence recommended for treatment of Campylobacter infection. The former study pointed out that all isolates were not sensitive to cotrimoxazole [25].

\subsection{Southern Africa}

A study in Durban, South Africa, reported 68\% and 64\% resistance to tetracycline in the isolates of Campylobacter from chicken and humans, respectively [89]. Also in Durban, Shobo, Bester, Baijnath, Somboro, Peer and Essack [90], reported that 31.5\%, 50\%, and 25.9\% of C. jejuni isolates from humans were resistant to erythromycin, azithromycin, and tetracycline, respectively; while $38.9 \%$, $77 \%$, and $55.6 \%$ of C. coli strains showed resistance to erythromycin, azithromycin, and erythromycin, respectively. In Campylobacter, resistance to tetracycline is primarily mediated by a ribosomal protection protein $(t e t \mathrm{O})$ that is transferred as a plasmid-encoded gene or in the chromosome where it is not self-mobile [90].

Production systems and bird type also have an influence on isolation rates and resistance. In the Kwazulu Natal province of South Africa, it was established that the isolates from commercially raised, i.e., free range and industrial chickens were highly resistant to tetracycline (98.9-100\%). Resistance to gentamicin and streptomycin was $1.6 \%$ and $11.5 \%$ respectively in the commercial free-range broiler, $1.7 \%$ and $16.4 \%$ in industrially raised broilers, and 12.9 and $40 \%$ respectively in industrially raised layers [92]. Different production systems use antibiotics differently and this accounted for the varied resistance profiles. In 2012, a study found higher resistance to ciprofloxacin in cattle than broilers in the Venda Region in the north of South Africa [91]. In chicken, C. jejuni showed a resistance of $29 \%$ to ciprofloxacin while in cattle the resistance was $33.3 \%$. However, resistance to erythromycin was higher at $56.7 \%$ and $42.9 \%$ in chicken and cattle respectively. Resistance to ciprofloxacin among chicken was due to the use of sarafloxacin and enrofloxacin on poultry farms. Additionally, Bester and Essack [28] found varying resistances to common antibiotics used in broilers and layers in Kwazulu Natal. For instance, resistance to tetracycline was $98.2 \%$ and $100 \%$ for broilers and layers respectively. Resistance to gentamicin was equally high at $98 \%$ for broilers and $81 \%$ for layers. Thirdly, multi-resistance was found in $23 \%$ and $43 \%$ of the isolates from broilers and layers, respectively.

\subsection{North Africa}

In Algeria, isolated strains from turkeys showed resistance to tetracycline at $81.3 \%$, ciprofloxacin at $75.0 \%$, and erythromycin at $25.0 \% .96 .9 \%$ of the isolates were multidrug resistant and $18 \mathrm{drug}$ resistance patterns were identified [77]. The authors in the previous study argued that the prudent use of fluoroquinolones contributed to the high resistance rates recorded in ciprofloxacin. The continuous use of fluoroquinolones in poultry production selects for fluoroquinolone-resistant mutants which leads to the emergence of resistant Campylobacter. The selection pressure presented by different antibiotics accounted for the varying rate of resistance and multidrug resistance trends recorded. Meryem, Zehor, Fares, Sadjia and Amina [29], also discovered that the isolates from livestock showed resistance of $91.6 \%$ to ciprofloxacin, $88.54 \%$ to erythromycin, and $44.7 \%$ to tetracycline in the middle area of Algeria. Resistance to ciprofloxacin and erythromycin were $91.6 \%$ and $88.54 \%$ respectively while that to tetracycline was $44.7 \%$.

Reports from Egypt indicated that Campylobacter isolates from poultry showed a 58.82\% resistance to erythromycin and tetracycline; whereas isolates from humans showed a resistance of $75 \%$ to tetracycline and $62.5 \%$ to erythromycin [57]. The inexpensive cost and broad-spectrum properties of tetracycline resulted in the widespread use in both humans and animals and consequently, the selective pressure led to the emergence of resistant genes. In addition, C. jejuni and C. coli isolates from diarrhoeal patients in Cairo showed $40 \%$ and $24 \%$ resistance to nalidixic acid, $6 \%$ and $24 \%$ to tetracycline and $9 \%$ and $10 \%$ resistance to erythromycin respectively [59]. 


\section{Management Strategies: Opportunities and Challenges}

A holistic, multiple intervention One Health approach is required to better understand, prevent, and control Campylobacter and its related infections. One Health recognizes that the health of people is connected to the health of animals and the environment. It is a collaborative, multisectoral, and transdisciplinary approach —working at the local, regional, national, and global levels-with the goal of achieving optimal health outcomes recognising the interconnection between people, animals, plants, and their shared environment (readers unfamiliar with the One Health concept could consult the following CDC website for an introduction: https://www.cdc.gov/onehealth/index.html). In the African context, management of Campylobacter can be dealt with at the domestic, farm, processing, and policy levels.

At the domestic setting level, several studies across Africa indicated a significant association between Campylobacter enteritis and contact with both animals $[32,41,42,93,94]$ and diarrhoea sick persons [32]. This creates a public health concern since agriculture, particularly the livestock sector, is a major source of livelihood in Africa. In rural areas where sometimes access to adequate medical intervention is unavailable the situation becomes more critical. Furthermore, the communal living culture in Africa tends to have healthy family members taking care of sick ones, and those with diarrhoea are no exceptions from receiving family care. It is important to minimise human-animal contact, practice personal and environmental hygiene, and seek proper medical care for sick persons in a household in order to minimise risks of transmission.

Animal production and management systems play an important part in Campylobacter control and must be carefully considered. Studies in Europe estimated that a three log unit reduction of Campylobacter load in the ceca of poultry would result to a more than $90 \%$ reduction of human infections attributed to poultry meat consumption [22]. Additionally, the animal production system influences antimicrobial usage and this has implications for antibiotic resistance. According to Jonker and Picard [84], in intensive poultry and pig rearing systems the use of oral antibiotics is essential to maintain health hence there is a high risk for the Campylobacter in the intestinal tract of food animals to develop resistance to commonly used antibiotics. In poultry flocks, the risk factors for Campylobacter introduction include the partial depopulation of flocks at several occasions, the increased age of sale, inadequate washing and disinfection of poultry houses, and poor levels of biosecurity measures such as absence of a footbath at the entrance and poor rodent control [95]. Treatment of drinking water and litter, rodent control on farms, and effective biosecurity are important management interventions to be employed on the farm [96]. Applying biosecurity interventions at poultry production sites has resulted in different levels of success in different countries $[6,14,97]$. Such variation may be attributed to differences in the Campylobacter loads in the poultry chain and environment. Hence, the effectiveness of biosecurity-related interventions in primary production should be based on a good understanding of the regional risk factors at the farm level.

In addition to primary interventions at the farm level, there is a need to apply interventions at the slaughter and processing levels in order to reduce the contamination of poultry meat meant for human consumption. Freezing of contaminated poultry carcasses is a reliable intervention to achieve a 1 to 2-log reduction of Campylobacter counts. The compulsory freezing of processed broilers from Campylobacter-positive broiler flocks in Iceland resulted in a substantially reduced number of human cases of Campylobacter enteritis and is currently being used on a voluntary basis in Norway, Sweden, and Denmark [14,22]. However, in Africa, freezing might not be a feasible option in many countries due to the added cost of energy used for freezing operations as well as challenges in keeping a sustainable cold chain in several countries with limited infrastructure. Many consumers across the African continent prefer to buy fresh poultry meat with no change in product quality [24].

Chemical decontamination can also be an effective intervention for reducing Campylobacter load on food animal carcasses, and the feasibility of this option could be appealing in the African context. Chlorine, chlorine dioxide, acidified sodium chlorite, trisodium phosphate, and peroxyacid are typically used in poultry processing in the United States and Australia either as sprays or washes for online 
reprocessing or added to the chill water tank $[7,9]$. However, pathogens decontamination using chemicals and its application to poultry carcasses should be well regulated and monitored, in order to avoid excessive use. Also the use of chemical decontamination should not be considered as a replacement, rather complimentary, to good processing practices in poultry abattoirs [14].

The lack of national surveillance data hinders the adequate assessment of the public health impact and burden of disease [7,22]. Most African countries have no national surveillance programs on Campylobacter. Therefore, getting the accurate burden of the disease is difficult [24]. Adopting multisector collaborations would help strengthen the disease surveillance system, enhance laboratory capacity, and support the implementation of prevention and control strategies; it would further enhance public health and veterinary laboratories and create intersectorial linkages to tackle zoonotic diseases [97]. In spite of technological advances, laboratories in many African countries still face challenges with isolation and identification of Campylobacter in food and clinical samples. Inadequately trained personnel, poor laboratory infrastructure, low funding for research on foodborne pathogens like Campylobacter are also major limiting factors in many countries across Africa.

\section{Conclusions}

Zoonotic pathogens such as Campylobacter cause disease and death, resulting in enormous social and economic losses. Significant gaps exist in the epidemiological understanding of Campylobacter in Africa, and its role as a diarrhoeal agent needs more attention. The present review highlights the variability in the reported occurrence of Campylobacter in humans and animal food sources across different countries and regions in Africa. Campylobacter infection is particularly prevalent in the paediatric population and has been isolated from farm animals, particularly poultry, and foods of animal origin. The reported prevalence of Campylobacter in children under the age of five years ranges from $2 \%$ in Sudan to $21 \%$ in South Africa. To better understand the magnitude of the campylobacteriosis burden, future research is required to evaluate the under-reporting of diarrhoea incidents at national and continental levels; this cannot be achieved without enhancing local capacities for disease surveillance and monitoring.

A holistic, multiple intervention One Health approach is required to better understand, prevent, and control Campylobacter in the African context. The management of the foodborne transmission of Campylobacter can be dealt with at the domestic, farm, processing, and policy levels. In poultry, the present review points that the prevalence ranges from $14.4 \%$ in Ghana to $96 \%$ in Algeria. This review also highlights the alarming trend across several countries in Africa of increased Campylobacter resistance to clinically important antimicrobials, such as ciprofloxacin and erythromycin, in humans and food animals.

In our opinion, and based on the evidence gathered in this review, we believe that Campylobacter infection is predicted to emerge further as a serious challenge that African nations will face in the near future. Children in low-resource settings countries across Africa will be suffering the most, given the high burden of infection, combined with the growing trend in Campylobacter resistance to clinically relevant antimicrobial. We still know little about from what, how, and where children contract infection. What role do domestic animals, which are known reservoirs of Campylobacter, play in transmission? Does infection result from fecal contamination in the environment and how long does Campylobacter survive in the environment? Although exposure to poultry may be important, identified determinants are varied across different regions in Africa. Given the paucity of current data, further research on Campylobacter in Africa is warranted. Epidemiological studies on risk factors and exposure routes would assist in devising appropriate interventions and strategies. However, it is important to prioritise the reduction of risk factors and exposure routes in all settings as a first step in management.

Author Contributions: Conceptualisation, I.H.; Methodology, I.H. and N.A.-B.; Writing-original draft, N.A.-B., A.P.-H.K., S.A. and I.H.; Writing-review \& editing, N.A.-B., A.P.-H.K. and I.H.

Funding: This research received no external funding. Nikki Asuming-Bediako is a PhD student supported by a scholarship from Murdoch University. 
Acknowledgments: This research is supported by an Australian Government Research Training Program (RTP) Scholarship awarded to Nikki Asuming-Bediako in support of her PhD study at Murdoch University.

Conflicts of Interest: The authors declare no conflict of interest.

\section{References}

1. Gharst, G.; Oyarzabal, O.A.; Hussain, S.K. Review of current methodologies to isolate and identify Campylobacter spp. from foods. J. Microbiol. Methods 2013, 95, 84-92. [CrossRef] [PubMed]

2. Adams, M.R.; Moss, M.O. Food Microbiology; The Royal Society of Chemistry: Cambridge, UK, 2008.

3. Padungton, P.; Kaneene, J.B. Campylobacter spp. in Humans, Chickens, Pigs and Their Antimicrobial Resistance. J. Vet. Med. Sci 2003, 65, 161-170. [CrossRef] [PubMed]

4. Elbrissi, A.; Sabeil, Y.A.; Khalifa, K.A.; Enan, K.; Khair, O.M.; El Hussein, A.M. Isolation, identification and differentiation of Campylobacter spp. using multiplex PCR assay from goats in Khartoum State, Sudan. Trop. Anim. Health Prod. 2017, 49, 575-581. [CrossRef] [PubMed]

5. Tafa, B.; Sewunet, T.; Tassew, H.; Asrat, D. Isolation and Antimicrobial Susceptibility Patterns of Campylobacter Species among Diarrheic Children at Jimma, Ethiopia. Int. J. Bacteriol. 2014, 2014, 560617. [CrossRef] [PubMed]

6. Goualie, G.B.; Essoh, E.A.; Elise Solange, K.N.; Natalie, G.; Souleymane, B.; Lamine Sebastien, N.; Mireille, D. Prevalence and Antimicrobial Resistance of Thermophilic Campylobacter Isolated from Chicken in Cote d'Ivoire. Int. J. Microbiol. 2012, 2012, 150612.

7. Butzler, J.P. Campylobacter, from obscurity to celebrity. Clin. Microbiol. Infect. 2004, 10, 868-876. [CrossRef] [PubMed]

8. Whiley, H.; van den Akker, B.; Giglio, S.; Bentham, R. The role of environmental reservoirs in human campylobacteriosis. Int. J. Environ. Res. Public Health 2013, 10, 5886-5907. [CrossRef] [PubMed]

9. WHO. WHO Estimates of the Global Burden of Foodborne Diseases; WHO: Geneva, Switzerland, 2015; p. 268.

10. Komba, E.V.G. Human and Animal Thermophilic Campylobacter infections in East African countries: Epidemiology and Antibiogram. Biomed. J. Sci. Tech. Res. 2017, 16, 17. [CrossRef]

11. Kaakoush, N.O.; Castano-Rodriguez, N.; Mitchell, H.M.; Man, S.M. Global Epidemiology of Campylobacter Infection. Clin. Microbiol. Rev. 2015, 28, 687-720. [CrossRef]

12. Havelaar, A.H.; van Pelt, W.; Ang, C.W.; Wagenaar, J.A.; van Putten, J.P.; Gross, U.; Newell, D.G. Immunity to Campylobacter: Its role in risk assessment and epidemiology. Crit. Rev. Microbiol. 2009, 35, 1-22. [CrossRef]

13. Ahs, J.W.; Tao, W.; Löfgren, J.; Forsberg, B.C. Diarrheal Diseases in Low- and Middle-Income Countries: Incidence, Prevention and Management. Open Infect. Dis. J. 2010, 4, 113-124. [CrossRef]

14. Humphrey, T.; O'Brien, S.; Madsen, M. Campylobacters as zoonotic pathogens: A food production perspective. Int. J. Food Microbiol. 2007, 117, 237-257. [CrossRef] [PubMed]

15. Dasti, J.I.; Tareen, A.M.; Lugert, R.; Zautner, A.E.; Gross, U. Campylobacter jejuni: A brief overview on pathogenicity-associated factors and disease-mediating mechanisms. Int. J. Med. Microbiol. 2010, 300, 205-211. [CrossRef] [PubMed]

16. Park, S.F. The physiology of Campylobacter species and its relevance to their role as foodborne pathogens. Int. J. Food Microbiol. 2000, 74, 177-188. [CrossRef]

17. Konkel, M.E.; Garvis, S.G.; Tipton, S.L.; Anderson, D.E.J.; Cieplak, W.J. Identification and molecular cloning of a gene encoding a fibronectin-binding protein (CadF) from Campylobacter jejuni. Mol. Microbiol. 1997, 24, 953-963. [CrossRef] [PubMed]

18. Carvalho, A.C.; Ruiz-Palacios, G.M.; Ramos-Cervantes, P.; Cervantes, L.E.; Jiang, X.; Pickering, L.K. Molecular characterization of invasive and noninvasive Campylobacter jejuni and Campylobacter coli isolates. J. Clin. Microbiol. 2001, 39, 1353-1359. [CrossRef] [PubMed]

19. Hickey, T.E.; Mcveigh, A.L.; Scott, D.A.; Michielutti, R.E.; Bixby, A.; Carroll, S.A.; Bourgeois, L.A.; Guerry, P. Campylobacter jejuni Cytolethal Distending Toxin Mediates Release of Interleukin-8 from Intestinal Epithelial Cells. Infect. Immun. 2000, 68, 6535-6541. [CrossRef]

20. Tresse, O.; Alvarez-Ordonez, A.; Connerton, I.F. Editorial: About the Foodborne Pathogen Campylobacter. Front. Microbiol. 2017, 8, 1908. [CrossRef]

21. Pesci, E.C.; Cottle, D.L.; Pickett, C.L. Genetic, Enzymatic, and Pathogenic Studies of the Iron Superoxide Dismutase of Campylobacter jejuni. Infect. Immun. 1994, 62, 2687-2694. 
22. WHO. The Global View of Campylobacteriosis; World Health Organization: Geneva, Switzerland, $2013 ;$ p. 69.

23. Samuel, S.O.; Aboderin, A.O.; Akanbi, A.A., II; Adegboro, B.; Smith, S.I.; Coker, A.O. Campylobacter enetritis in Ilorin, Nigeria. East Afr. Med. J. 2006, 83, 478-484.

24. Coker, A.O.; Isokpehi, R.D.; Thomas, B.N.; Amisu, K.O.; Obi, C.L. Human Campylobacteriosis in Developing Countries. Emerg. Infect. Dis. 2002, 8, 237-243. [CrossRef] [PubMed]

25. Adekunle, O.C.; Coker, A.O.; Kolawole, D.O. Antibiotic susceptibility pattern of strains of Campylobacter coli isolated in Osogbo, Nigeria. Biol. Med. 2009, 1, 20-23.

26. Moyane, J.N.; Jideani, A.I.O.; Aiyegoro, O.A. Antibiotics usage in food-producing animals in South Africa and impact on human: Antibiotic resistance. Afr. J. Microbiol. Res. 2013, 7, 2990-2997.

27. Mshana, S.E.; Joloba, M.; Kakooza, A.; Kaddu-Mulindwa, D. Campylobacter spp among Children with acute diarrhea attending Mulago hospital in Kampala-Uganda. Afr. Health Sci. 2009, 9, 201-205. [PubMed]

28. Bester, L.A.; Essack, S.Y. Prevalence of antibiotic resistance in Campylobacter isolates from commercial poultry suppliers in KwaZulu-Natal, South Africa. J. Antimicrob. Chemother. 2008, 62, 1298-1300. [CrossRef] [PubMed]

29. Meryem, G.; Zehor, G.; Fares, A.; Sadjia, M.; Amina, H. Campylobacter in sheep, calves and broiler chickens in the central region of Algeria: Phenotypic and antimicrobial resistance profiles. Afr. J. Microbiol. Res. 2016, 10, 1662-1667. [CrossRef]

30. UNSD Methodology. Available online: www.unstats.un.org/unsd/methodology/m49/ (accessed on 8 April 2019).

31. Lengerh, A.; Moges, F.; Unakal, C.; Anagaw, B. Prevalence, associated risk factors and antimicrobial susceptibility pattern of Campylobacter species among under five diarrheic children at Gondar University Hospital, Northwest Ethiopia. BMC Pediatr. 2013, 13, 82. [CrossRef] [PubMed]

32. Mitike, G.; Kassu, A.; Genetu, A.; Nigussie, D. Campylobacter enteritis among children in Dembia District, Northwest Ethiopia. East Afr. Med. J. 2000, 77, 654-657. [CrossRef]

33. Swierczewski, B.E.; Odundo, E.A.; Koech, M.C.; Ndonye, J.N.; Kirera, R.K.; Odhiambo, C.P.; Cheruiyot, E.K.; Shaffer, D.N.; Ombogo, A.N.; Oak, E.V. Enteric pathogen surveillance in a case-control study of acute diarrhea in Kisii Town, Kenya. J. Med. Microbiol. 2013, 62 Pt 11, 1774-1776. [CrossRef]

34. Randremanana, R.; Randrianirina, F.; Gousseff, M.; Dubois, N.; Razafindratsimandresy, R.; Hariniana, E.R.; Garin, B.; Randriamanantena, A.; Rakotonirina, H.C.; Ramparany, L.; et al. Case-control study of the etiology of infant diarrheal disease in 14 districts in Madagascar. PLoS ONE 2012, 7, e44533. [CrossRef] [PubMed]

35. Mason, J.; Iturriza-Gomara, M.; O’Brien, S.J.; Ngwira, B.M.; Dove, W.; Maiden, M.C.; Cunliffe, N.A. Campylobacter infection in children in Malawi is common and is frequently associated with enteric virus co-infections. PLoS ONE 2013, 8, e59663. [CrossRef] [PubMed]

36. Mandomando, M.I.; Macete, V.E.; Ruiz, J.; Sanz, S.; Abacassamo, F.; Valles, X.; Sacarlal, J.; Navia, M.M.; Vila, J.; Pedro, L.P.; et al. Etiology of Diarrhea in Children Younger than 5 years Of Age Admitted in A Rural Hospital of Southern Mozambique. Am. J. Trop. Med. Hyg. 2007, 76, 522-527. [CrossRef] [PubMed]

37. Komba, E.V.; Mdegela, R.H.; Msoffe, P.L.; Nielsen, L.N.; Ingmer, H. Prevalence, Antimicrobial Resistance and Risk Factors for Thermophilic Campylobacter Infections in Symptomatic and Asymptomatic Humans in Tanzania. Zoonoses Public Health 2015, 62, 557-568. [CrossRef] [PubMed]

38. Deogratias, A.-P.; Mushi, M.F.; Paterno, L.; Tappe, D.; Seni, J.; Kabymera, R.; Kidenya, B.R.; Mshana, S.E. Prevalence and determinants of Campylobacter infection among under five children with acute watery diarrhea in Mwanza, North Tanzania. Arch. Public Health 2014, 72, 17. [CrossRef] [PubMed]

39. Mdegela, R.H.; Nonga, H.E.; Ngowi, H.A.; Kazwala, R.R. Prevalence of Thermophilic Campylobacter Infections in Humans, Chickens and Crows in Morogoro, Tanzania. J. Vet. Med. 2006, 53, 116-121. [CrossRef] [PubMed]

40. Pelkonen, T.; Dos Santos, M.D.; Roine, I.; Dos Anjos, E.; Freitas, C.; Peltola, H.; Laakso, S.; Kirveskari, J. Potential Diarrheal Pathogens Common Also in Healthy Children in Angola. Pediatr. Infect. Dis. J. 2018, 37, 424-428. [CrossRef] [PubMed]

41. Sangaré, L.; Nikiéma, A.K.; Zimmermann, S.; Sanou, I.; Congo-Ouédraogo, M.; Diabaté, A.; Diandé, S.; Guissou, P.I. Campylobacter Spp. Epidemiology and Antimicrobial Susceptibility in a Developing Country, Burkina Faso (West Africa). Afr. J. Clin. Exp. Microbiol. 2012, 13, 110-117. [CrossRef]

42. Karikari, A.B.; Obiri-Danso, K.; Frimpong, E.H.; Krogfelt, K.A. Antibiotic Resistance in Campylobacter Isolated from Patients with Gastroenteritis in a Teaching Hospital in Ghana. Open J. Med. Microbiol. 2017, 7, 1-11. [CrossRef] 
43. Molbak, K.; Hojlyng, N.; Gaarslev, K. High prevalence of campylobacter excretors among Liberian children related to environmental conditions. Epidem. Inf. 1988, 100, 227-237. [CrossRef]

44. Nwankwo, I.O.; Faleke, O.O.; Salihu, M.D.; Magaji, A.A.; Musa, U.; Garba, J. Epidemiology of Campylobacter species in poultry and humans in the four agricultural zones of Sokoto State, Nigeria. J. Public Health Epidemiol. 2016, 8, 184-190.

45. Nwankwo, I.O.; Faleke, O.O.; Salihu, M.D.; Magaji, A.A.; Shu-Yun, Z. Prevalence of Campylobacter Species in Out-patients And Pregnant Women Attending Government Clinics in Sokoto State, Nigeria. J. Prev. Med. Care 2016, 1, 8-15.

46. Ohanu, M.E.; Offune, J. The prevalence of Campylobacter in childhood diarrhea in Enugu State of Nigeria. J. Commun. Dis. 2009, 41, 117-120. [PubMed]

47. Samie, A.; Obi, C.L.; Barrett, L.J.; Powell, S.M.; Guerrant, R.L. Prevalence of Campylobacter species, Helicobacter pylori and Arcobacter species in stool samples from the Venda region, Limpopo, South Africa: Studies using molecular diagnostic methods. J. Infect. 2007, 54, 558-566. [CrossRef] [PubMed]

48. Samie, A.; Ramalivhana, J.; Igumbor, E.O.; Obi, C.L. Prevalence, haemolytic and haemagglutination activities and antibiotic susceptibility profiles of Campylobacter spp. isolated from human diarrhoeal stools in Vhembe District, South Africa. J. Health Popul. Nutr. 2007, 25, 406-413. [PubMed]

49. Lastovica, A.J. Emerging Campylobacter spp.: The Tip of the Iceberg. Clin. Microbiol. Newsl. 2006, 28 , 49-56. [CrossRef]

50. Obi, C.L.; Bessong, P.O. Diarrhoeagenic bacterial pathogens in HIV-positive patients with diarrhoea in rural communities of Limpopo Province, South Africa. J. Health Popul. Nutr. 2002, 20, 230-234.

51. Mackenjee, M.K.; Coovadia, Y.M.; Coovadia, H.M.; Hewitt, J.; Robins-Browne, R.M. Aetiology of diarrhoea in adequately nourished young African children in Durban, South Africa. Ann. Trop. Paediatr. 1984, 4, 183-187. [CrossRef]

52. Abushahba, M.F.N. Prevalence of Zoonotic Species of Campylobacter in Broiler Chicken and Humans in Assiut Governorate, Egypt. Approaches Poult. Dairy Vet. Sci. 2018, 3, 1-9. [CrossRef]

53. Sainato, R.; ElGendy, A.; Poly, F.; Kuroiwa, J.; Guerry, P.; Riddle, M.S.; Porter, C.K. Epidemiology of Campylobacter Infections among Children in Egypt. Am. J. Trop. Med. Hyg. 2018, 98, 581-585. [CrossRef]

54. El-Tras, W.F.; Holt, H.R.; Tayel, A.A.; El-Kady, N.N. Campylobacter infections in children exposed to infected backyard poultry in Egypt. Epidemiol. Infect. 2015, 143, 308-315. [CrossRef]

55. Omara, S.T.; Fadaly, H.A.E.; Barakat, A.M.A. Public Health Hazard of Zoonotic Campylobacter jejuni Reference to Egyptian Regional and Seasonal Variations. Res. J. Microbiol. 2015, 10, 343-354. [CrossRef]

56. Awadallah, M.A.I.; Ahmed, H.A.; El-Gedawy, A.A.; Saad, A.M. Molecular identification of C. jejuni and C. coli in chicken and humans, at Zagazig, Egypt, with reference to the survival of $\mathrm{C}$. jejuni in chicken meat at refrigeration and freezing temperatures. Int. Food Res. J. 2014, 21, 1801-1812.

57. Hassanain, N.A. Antimicrobial Resistant Campylobacter jejuni Isolated from Humans and Animals in Egypt. Glob. Vet. 2011, 6, 195-200.

58. Rao, M.R.; Naficy, A.B.; Savarino, S.J.; Abu-Elyazeed, R.; Wierzba, T.; Peruski, L.; Abdel-Messih, I.A.; Frenck, R.R.; Clemens, J.D. Pathogenicity and Convalescent Excretion of Campylobacter in Rural Egyptian Children. Am. J. Epidemiol. 2001, 154, 166-173. [CrossRef] [PubMed]

59. Wasfy, M.O.; Oyofo, B.A.; David, J.C.; Ismail, T.F.; El-Gendy, A.M.; Mohran, Z.S.; Sultan, Y.; Peruski, L.F. Isolation and Antibiotic Susceptibility of Salmonella, Shigella, and Campylobacter from Acute Enteric Infections in Egypt. J. Health Popul. Nutr. 2000, 18, 33-38. [PubMed]

60. Saeed, A.; Abd, H.; Sandstrom, G. Microbial aetiology of acute diarrhoea in children under five years of age in Khartoum, Sudan. J. Med. Microbiol. 2015, 64 Pt 4, 432-437. [CrossRef]

61. Heikema, A.P.; Islam, Z.; Horst-Kreft, D.; Huizinga, R.; Jacobs, B.C.; Wagenaar, J.A.; Poly, F.; Guerry, P.; van Belkum, A.; Parker, C.T.; et al. Campylobacter jejuni capsular genotypes are related to Guillain-Barre syndrome. Clin. Microbiol. Infect. 2015, 21, 852.e1-852.e9. [CrossRef]

62. Paudyal, N.; Anihouvi, V.; Hounhouigan, J.; Matsheka, M.I.; Sekwati-Monang, B.; Amoa-Awua, W.; Atter, A.; Ackah, N.B.; Mbugua, S.; Asagbra, A.; et al. Prevalence of foodborne pathogens in food from selected African countries-A meta-analysis. Int. J. Food Microbiol. 2017, 249, 35-43. [CrossRef]

63. Woldemariam, T.; Asrat, D.; Zewde, G. Prevalence of Thermophilic Campylobacter species in carcasses from sheep and goats in an abattoir in Debre Zeit area, Ethiopia. Ethiop. J. Health Dev. 2009, 23, 229-232. [CrossRef] 
64. Osano, O.; Arimi, S.M. Retail Poultry and Beef as Sources of Campylobacter jejuni. East Afr. Med. J. 1999, 76, 141-143.

65. Kashoma, I.P.; Kassem, I.I.; John, J.; Kessy, B.M.; Gebreyes, W.; Kazwala, R.R.; Rajashekara, G. Prevalence and Antimicrobial Resistance of Campylobacter Isolated from Dressed Beef Carcasses and Raw Milk in Tanzania. Microb. Drug Resist. 2016, 22, 40-52. [CrossRef] [PubMed]

66. Nonga, H.E.; Muhairwa, A.P. Prevalence and antibiotic susceptibility of thermophilic Campylobacter isolates from free range domestic duck (Cairina moschata) in Morogoro municipality, Tanzania. Trop. Anim. Health Prod. 2010, 42, 165-172. [CrossRef] [PubMed]

67. Nonga, H.E.; Sells, P.; Karimuribo, E.D. Occurrences of thermophilic Campylobacter in cattle slaughtered at Morogoro municipal abattoir, Tanzania. Trop. Anim. Health Prod. 2010, 42, 73-78. [CrossRef]

68. Nzouankeu, A.; Ngandjio, A.; Ejenguele, G.; Njine, T.; Wouafo, M.N. Multiple contaminations of chickens with Campylobacter, Escherichia coli and Salmonella in Yaounde (Cameroon). J. Infect. Dev. Ctries. 2010, 4, 583-586. [PubMed]

69. Mpalang, R.K.; Boreux, R.; Melin, P.; Akir Ni Bitiang, K.; Daube, G.; De Mol, P. Prevalence of Campylobacter among goats and retail goat meat in Congo. J. Infect. Dev. Ctries. 2014, 8, 168-175. [CrossRef] [PubMed]

70. Kagambèga, A.; Thibodeau, A.; Trinetta, V.; Soro, D.K.; Sama, F.N.; Bako, É.; Bouda, C.S.; Wereme N’Diaye, A.; Fravalo, P.; Barro, N. Salmonella spp. and Campylobacter spp. in poultry feces and carcasses in Ouagadougou, Burkina Faso. Food Sci. Nutr. 2018, 6, 1601-1606. [CrossRef] [PubMed]

71. Karikari, A.B.; Obiri-Danso, K.; Frimpong, E.H.; Krogfelt, K.A. Multidrug resistant Campylobacter in faecal and carcasses of commercially produced poultry. Afr. J. Microbiol. Res. 2017, 11, 271-277.

72. Karikari, A.B.; Obiri-Danso, K.; Frimpong, E.H.; Krogfelt, K.A. Antibiotic Resistance of Campylobacter Recovered from Faeces and Carcasses of Healthy Livestock. BioMed Res. Int. 2017, 2017, 4091856. [CrossRef]

73. Salihu, M.D.; Junaidu, A.U.; Magaji, A.A.; Rabiu, Z.M. Study of Campylobacter in Raw Cow Milk in Sokoto State, Nigeria. Br. J. Dairy Sci. 2010, 1, 1-5.

74. Salihu, M.D.; Junaidu, A.U.; Magaji, A.A.; Abubakar, M.B.; Adamu, A.Y.; Yakubu, A.S. Prevalence of Campylobacter in poultry meat in Sokoto, Northwestern Nigeria. J. Public Health Epidemiol. 2009, 1, 041-045.

75. Cardinale, E.; Perrier Gros-Claude, J.D.; Tall, F.; Cissé, M.; Guèye, E.F.; Salvat, G. Prevalence of Salmonella and Campylobacter in Retail Chicken Carcasses in Senegal. Rev. d'élevage Méd. Vét. Pays Trop. 2003, 56, $13-16$.

76. van Nierop, W.; Duse, A.G.; Marais, E.; Aithma, N.; Thothobolo, N.; Kassel, M.; Stewart, R.; Potgieter, A.; Fernandes, B.; Galpin, J.S.; et al. Contamination of chicken carcasses in Gauteng, South Africa, by Salmonella, Listeria monocytogenes and Campylobacter. Int. J. Food Microbiol. 2005, 99, 1-6. [CrossRef]

77. Bouhamed, R.; Bouayad, L.; Messad, S.; Zenia, S.; Naim, M.; Hamdi, T.-M. Sources of contamination, prevalence, and antimicrobial resistance of thermophilic Campylobacter isolated from turkeys. Vet. World 2018, 11, 1074-1081. [CrossRef] [PubMed]

78. Laidouci, A.A.H.; Mouffok, F.; Hellal, A. Detection of Campylobacter in poultry in Algeria: Antibacterial profile determination. Rev. Méd. Vét. 2013, 164, 307-311.

79. El-Zamkan, M.A.; Hameed, K.G. Prevalence of Campylobacter jejuni and Campylobacter coli in raw milk and some dairy products. Vet. World 2016, 9, 1147-1151. [CrossRef] [PubMed]

80. El-Sharoud, W.M. Prevalence and survival of Campylobacter in Egyptian dairy products. Food Res. Int. 2009, 42, 622-626. [CrossRef]

81. Jouahri, M.; Asehraou, A.; Karib, H.; Hakkou, A.; Touhami, M. Prevalence and Control of Thermotolerant Campylobacter Species in Raw Poultry Meat in Morocco. MESO 2007, 9, 262-267.

82. Moore, J.E.; Barton, M.D.; Blair, I.S.; Corcoran, D.; Dooley, J.S.; Fanning, S.; Kempf, I.; Lastovica, A.J.; Lowery, C.J.; Matsuda, M.; et al. The epidemiology of antibiotic resistance in Campylobacter. Microbes Infect. 2006, 8, 1955-1966. [CrossRef]

83. de Vries, S.P.W.; Vurayai, M.; Holmes, M.; Gupta, S.; Bateman, M.; Goldfarb, D.; Maskell, D.J.; Matsheka, M.I.; Grant, A.J. Phylogenetic analyses and antimicrobial resistance profiles of Campylobacter spp. from diarrhoeal patients and chickens in Botswana. PLoS ONE 2018, 13, e0194481. [CrossRef]

84. Jonker, A.; Picard, J.A. Antimicrobial susceptibility in thermophilic Campylobacter species isolated from pigs and chickens in South Africa. J. S. Afr. Vet. Assoc. 2010, 81, 228-236. [CrossRef] 
85. Ghunaim, H.; Behnke, J.M.; Aigha, I.; Sharma, A.; Doiphode, S.H. Analysis of resistance to antimicrobials and presence of virulence/stress response genes in Campylobacter isolates from patients with severe diarrhoea. PLoS ONE 2015, 10, e0119268. [CrossRef] [PubMed]

86. Iovine, N.M. Resistance mechanisms in Campylobacter jejuni. Virulence 2013, 4, 230-240. [CrossRef] [PubMed]

87. Nguyen, T.N.; Hotzel, H.; Njeru, J.; Mwituria, J.; El-Adawy, H.; Tomaso, H.; Neubauer, H.; Hafez, H.M. Antimicrobial resistance of Campylobacter isolates from small scale and backyard chicken in Kenya. Gut Pathog. 2016, 8, 39. [CrossRef] [PubMed]

88. Salihu, M.D.; Junaidu, A.U.; Magaji, A.A.; Yakubu, Y. Prevalence and Antimicrobial Resistance of Thermophilic Campylobacter Isolates from Commercial Broiler Flocks in Sokoto, Nigeria. Res. J. Vet. Sci. 2012, 5, 51-58. [CrossRef]

89. Reddy, S.; Zishiri, O.T. Detection and prevalence of antimicrobial resistance genes in Campylobacter spp. isolated from chickens and humans. Onderstepoort J. Vet. Res. 2017, 84, e1-e6. [CrossRef] [PubMed]

90. Shobo, C.O.; Bester, L.A.; Baijnath, S.; Somboro, A.M.; Peer, A.K.; Essack, S.Y. Antibiotic resistance profiles of Campylobacter species in the South Africa private health care sector. J. Infect. Dev. Ctries. 2016, 10, 1214-1221. [CrossRef]

91. Uaboi-Egbenni, P.O.; Bessong, P.O.; Samie, A.; Obi, C.L. Potentially pathogenic Campylobacter species among farm animals in rural areas of Limpopo province, South Africa: A case study of chickens and cattles. Afr. J. Microbiol. Res. 2012, 6, 2835-2843. [CrossRef]

92. Bester, L.A.; Essack, S.Y. Observational study of the prevalence and antibiotic resistance of Campylobacter spp. from different poultry production systems in KwaZulu-Natal, South Africa. J. Food Prot. 2012, 75, 154-159. [CrossRef]

93. Wierzba, T.F.; Abdel-Messih, I.A.; Gharib, B.; Baqar, S.; Hendaui, A.; Khalil, I.; Omar, T.A.; Khayat, H.E.; Putnam, S.D.; Sanders, J.W.; et al. Campylobacter infection as a trigger for Guillain-Barre syndrome in Egypt. PLoS ONE 2008, 3, e3674. [CrossRef]

94. Klous, G.; Huss, A.; Heederik, D.J.J.; Coutinho, R.A. Human-livestock contacts and their relationship to transmission of zoonotic pathogens, a systematic review of literature. One Health 2016, 2, 65-76. [CrossRef]

95. Mageto, L.M.; Ombui, J.N.; Mutua, F.K. Prevalence and risk factors for Campylobacter infection of chicken in peri-urban areas of Nairobi, Kenya. J. Dairy Vet. Anim. Res. 2018, 7, 22-27. [CrossRef]

96. Orhan, S.; Issmat, I.K.; Zhangqi, S.; Jun, L.; Gireesh, R.; Qijing, Z. Campylobacter in Poultry: Ecology and Potential Interventions. Avian Dis. 2015, 59, 185-200.

97. Pieracci, E.G.; Hall, A.J.; Gharpure, R.; Haile, A.; Walelign, E.; Deressa, A.; Bahiru, G.; Kibebe, M.; Walke, H.; Belay, E. Prioritizing zoonotic diseases in Ethiopia using a one health approach. One Health 2016, 2, 131-135. [CrossRef] [PubMed]

(C) 2019 by the authors. Licensee MDPI, Basel, Switzerland. This article is an open access article distributed under the terms and conditions of the Creative Commons Attribution (CC BY) license (http://creativecommons.org/licenses/by/4.0/). 